MARCO ANTONIO ARAP

\title{
Estudo da proteína de choque térmico GRP78 para o desenvolvimento de um sistema de receptor-ligante para 0 câncer de próstata
}

Tese apresentada à Faculdade de Medicina da Universidade de São Paulo para obtenção do título de Doutor em Ciências

Área de concentração: Urologia

Orientador: Prof.Dr. Álvaro Sadek Sarkis

São Paulo

2003 


\section{FICHA CATALOGRÁFICA}

Preparada pela Biblioteca da Faculdade de Medicina da Universidade de São Paulo

Creprodução autorizada pelo autor

Arap, Marco Antonio

Estudo da proteína de choque térmico GRP78 para o desenvolvimento de um sistema de receptor-ligante para o câncer de próstata / Marco Antonio Arap. -- São Paulo, 2003.

Tese(doutorado)--Faculdade de Medicina da Universidade de São Paulo. Departamento de Cirurgia.

Área de concentração: Urologia.

Orientador: Álvaro Sadek Sarkis.

Descritores: 1.NEOPLASIAS PROSTÁTICAS/diagnóstico 2.NEOPLASIAS PROSTÁTICAS/genética 3.EXPRESSÃO GÊNICA/genética 4.MARCADORES BIOLÓGICOS DE TUMOR/análise 5.METÁSTASE NEOPLÁSICA 6.ESTADIAMENTO DE NEOPLASIAS 7.BACTERIÓFAGOS/crescimento \& desenvolvimento 8.BACTERIÓFAGOS/genética 9.IMUNOHISTOQUÍMICA / métodos 10.ELISA/métodos 11.SÍTIOS DE LIGAÇÃO (MICROBIOLOGIA)/ genética 12.LIGANTES 13.CAMUNDONGOS NUS 
"Há verdadeiramente duas coisas diferentes: saber e crer que se sabe. A ciência consiste em saber; em crer que se sabe, reside a ignorância."

(Hipócrates) 
Aos meus amados e mais do que presentes pais, Astrid e Sami, pela sua dedicação, apoio, carinho e amor sem limites. Deles herdei o verdadeiro prazer pelo estudo da Medicina.
À minhas irmãs Francine e Astrid e aos meus cunhados Victor e Julio, pela amizade sincera.
À meus sobrinhos
Victor e Stephanie,
alegrias da família.

\begin{abstract}
À meus queridos avós Wadih, Antonio, Zackie e Najla, exemplos a serem seguidos.
\end{abstract}

Aos pacientes que me deram o privilégio de poder acompanhá-los

e aos que ainda hei de tratar, a quem espero poder ajudar com a realização deste trabalho. 


\section{AGRADECIMENTOS}

- Ao meu pai e Prof. Sami Arap, a quem amo e admiro não só pela sua capacidade profissional, social e humana, que me dirigem e sempre hão de me inspirar em todas as dificuldades e conquistas de minha carreira, mas também pela sua dedicação à família, valor maior em minha vida.

- Ao meu Orientador, Prof. Dr. Álvaro Sadek Sarkis, a quem tenho profundo respeito e admiração pelo profissional e pela pessoa que representa, e a quem agradeço o apoio e aprendizado que me proporcionou.

- A meus orientadores americanos, Prof. Dr. Wadih Arap e Profa. Dra. Renata Pasqualini, cuja contribuição foi indispensável em todas as etapas deste trabalho, tanto do ponto de vista científico como operacional. Os Drs. Arap e Pasqualini são os diretores do Laboratório $\mathrm{A} / \mathrm{P}$, pertencente aos Departamentos de Biologia do Câncer e Oncologia Gênito-Urinária do M. D. Anderson Cancer Center, Universidade do Texas (UT), Houston, onde todos os experimentos científicos desta Tese foram executados.

- Ao Prof. Dr. Christopher Logothetis, Chefe do Departamento de Oncologia Gênito-Urinária do M. D. Anderson Cancer Center, Universidade do Texas, Houston, por me ter aceito como fellow em Uro-oncologia no seu programa e por me proporcionar total apoio em todos os momentos da minha estadia no exterior.

- Aos meus colegas no Laboratório de Oncologia Gênito-Urinária da UT, pelas suas contribuições, ensinamentos, auxílio, atenção e simpatia: Johanna Lahdenranta, Amin Hajitou, Paul J. Mintz, Mikhail Kolonin, Amado Zurita, Limor Chen, Laura Bover, Akihiko Kunyiasu, Catherine 
Moya, Marina Cardó-Vila, Connie Sun, Jessica Sun, Katherine Leskin, Michael Osawa e Israel Ramirez.

- Ao amigo Dr. Leopoldo Alves Ribeiro Filho, pelo auxílio e pelas sugestões na elaboração desta Tese, agradeço a amizade e o apoio, sempre presentes na realização deste trabaho.

- Aos Drs. Jose Roberto Colombo Jr., Luis Baltazar Saldanha e Ioannis Michel Antonopoulos, do Hospital das Clínicas da Faculdade de Medicina da Universidade de São Paulo, pelas contribuições na coleta do material estudado.

- Aos colegas médicos, enfermeiros, auxiliares e funcionários da Disciplina de Urologia da Faculdade de Medicina da Universidade de São Paulo, pela atenção e paciência na minha formação

- Aos Profs. Drs. Anuar Ibrahim Mitre, Flávio Eduardo Trigo Rocha e Emannuel Dias Neto, pelas suas preciosas sugestões quando da aula de qualificação.

- À Dra. Kim-Anh Doh pela revisão da análise estatística empregada nesta Tese.

- À Elisa de Arruda Cruz da Silva e Maria de Fátima Diniz, pelo auxílio prestado durante a pós-graduação.

- Às Srta. Kay Brown e Sra. Monica Tucker, funcionárias do Departamento de Oncologia Gênito-Urinária do M. D. Anderson Cancer Center, Universidade do Texas, Houston, pela sua atenção e ajuda durante todo o período que desenvolvi esta Tese no exterior.

- Aos pacientes, motivação principal de minha carreira, que gentilmente permitiram a obtenção das amostras teciduais utilizadas neste estudo

- A todas as outras pessoas que tenham participado direta ou indiretamente de qualquer etapa deste trabalho. 
- O presente estudo foi financiado pelas bolsas de números CA90270, CA8297601, CA908001, do National Institutes of Health, EUA; por prêmios da Fundações Gillson-Longenbaugh, Fundação V, AngelWorks e CaP CURE. 


\section{SUMÁRIO}

\section{LISTA DE ABREVIATURAS}

LISTA DE QUADROS

\section{LISTA DE TABELAS}

\section{LISTA DE FIGURAS}

\section{RESUMO}

\section{SUMMARY}

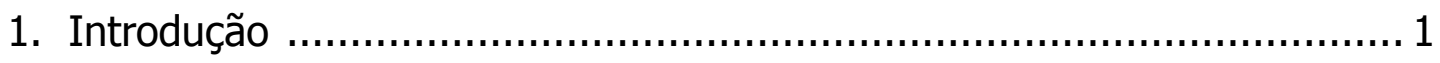

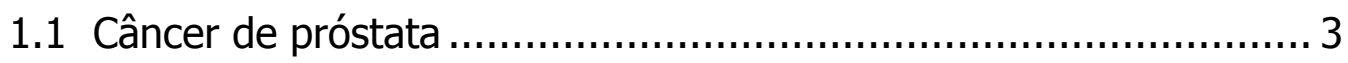



1.1 .2 Fatores de risco ........................................................ 4

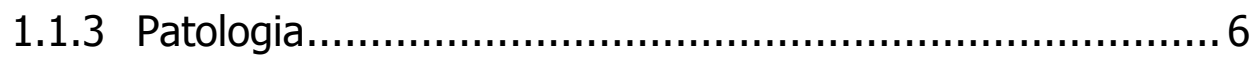

1.1.3.1 Tipos Histológicos.......................................... 6

1.1.3.2 Classificação e estadiamento ............................... 6

1.1.4 Tratamento do câncer de próstata avançado.....................9

1.2 Tecnologia de apresentação de bacteriófagos ............................ 10

1.3 As proteínas reguladas pela glicose (Glucose-regulated

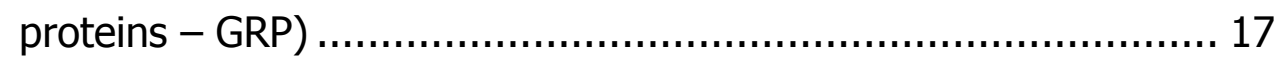

1.4 Proteína-78 regulada pela glicose (Glucose-regulated protein-78 - GRP78) .................................................. 18



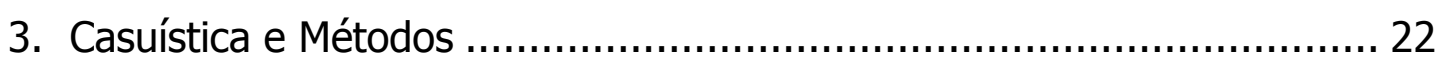

3.1 Clonagem dos peptídeos selecionados com afinidade à proteína GRP78 no vetor fUSE5 ....................................... 23

3.2 Testes de ligação dos fagos in vitro ......................................... 26

3.3 Inibição da ligação dos fagos in vitro com os peptídeos sintéticos. 
3.4 Ligação dos fagos à células prostáticas malignas DU145.............. 28

3.5 Inibição da ligação dos fagos às células prostáticas

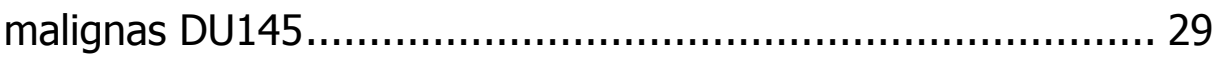

3.6 Internalização dos fagos pelas células prostáticas DU145 …......... 30

3.7 Estabelecimento dos modelos animais de câncer de

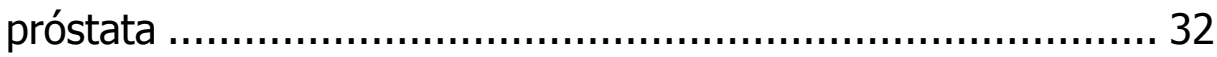

3.8 Ensaio de rastreamento dos tumores prostáticos in vivo............... 34

3.9 Imunohistoquímica para deteç̧ão de fagos nos modelos animais de xeno-tumores prostáticos .................................... 35

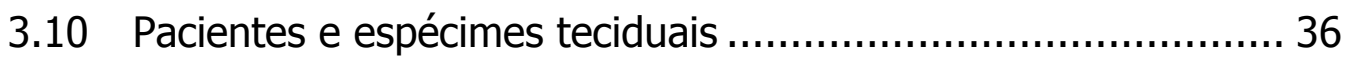

3.11 Ensaios de sobreposição de fagos em metástases ósseas de adenocarcinoma de próstata ................................. 38



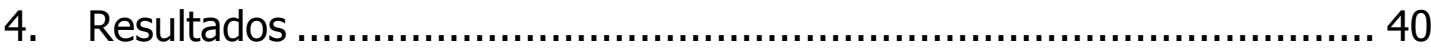

4.1 Seleção de peptídeos, clonagem e amplificação dos fagos com afinidade à proteína de choque térmico GRP78 ................ 41

4.2 Ligação específica dos fagos à proteína GRP78 in vitro................. 42

4.3 Ligação específica dos fagos à células de câncer de próstata que expressam a GRP78 ........................................ 49

4.4 Internalização dos fagos pelas células prostáticas malignas DU145 53

4.5 Ligação dos fagos a tumores prostáticos in vivo.......................... 55

4.6 Ligação específica dos fagos à metástases ósseas de câncer de próstata



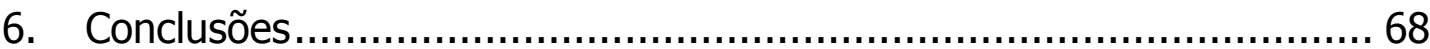

7. Referências Bibliográficas ............................................................. 70 


\section{LISTA DE ABREVIATURAS}

$\begin{array}{ll}\text { AJCC } & \text { American Joint Committee on Cancer } \\ \text { BSA } & \text { Albumina sérica bovina } \\ \text { DAB } & 3,3 \text { Diaminobenzidina tetrahidrocloreto } \\ \text { DMEM } & \text { Dulbecco's Modified Eagle Medium } \\ \text { DNA } & \text { Ácido desoxirribonucléico } \\ \text { EDTA } & \text { ácido etileno diamino tetracético } \\ \text { et al. } & \text { e outros } \\ \text { FACS } & \text { Fluorescent activated cell sorting } \\ \text { g } & \text { gravidade } \\ \text { GRP78 } & \text { Glucose regulated protein 78 } \\ \text { HSP70 } & \text { Heat-shock protein 70 } \\ \text { HSP90 } & \text { Heat-shock protein } 90 \\ \text { IgG } & \text { Imunoglobulina G } \\ \text { PBS } & \text { solução de NaCl a 0.9\% tamponada com fosfato } \\ \text { PCR } & \text { Reação em cadeia de polimerase } \\ \text { PEG } & \text { Polietileno glicol } \\ \text { RGD } & \begin{array}{l}\text { Arginina-Glicina-Aspártico, de acordo com o IUB-IUPAC } \\ \text { (International Union of Biochemistry - International Union } \\ \text { of Pure and Applied Chemistry - vide quadro 2). Idem para } \\ \text { outras sequências mencionadas } \\ \text { TNM }\end{array} \text { Metastasis) } \\ \text { UT } & \text { Unidades transducentes } \\ & \end{array}$




\section{LISTA DE QUADROS}

Quadro 1. Classificação TNM para o câncer de próstata. .......................... 8

Quadro 2. Sequência de DNA clonadas no vetor fUSE5, codificadoras dos 5 peptídeos selecionados (código de aminoácidos do IUB-IUPAC).....

\section{LISTA DE TABELAS}

Tabela 1. Sumário dos dados demográficos dos pacientes adenocarcinoma de próstata metastático

Tabela 2. Resultados representativos da ligação dos fagos à proteína GRP78 e às proteínas controle in vitro. 


\section{LISTA DE FIGURAS}

Figura 1. Esquema da estrutura do bacteriófago................................ 11

Figura 2. Utilização da tecnologia de apresentação de fagos................... 13

Figura 3. Esquema da utilização de fagos in vivo ................................. 15

Figura 4. Exemplo de xeno-enxerto de adenocarcinoma de próstata em camundongo tipo "nude".................................... 33

Figura 5. Comparação da ligação in vitro do fago 1 (WIFPWIQL) às proteínas controle (BSA, HSP70 e HSP90) ............................ 43

Figura 6. Comparação da ligação in vitro do fago 4 (WDLAWMFRLPVG) às proteínas controle (BSA, HSP70 e HSP90)

Figura 7. Inibição dose-dependente da ligação do fago 1 (WIFPWIQL) à proteína GRP78.

Figura 8. Inibição dose-dependente da ligação do fago 4 (WDLAWMFRLPVG) à proteína GRP78. 48

Figura 9. Ligação do fago 1 (WIFPWIQL) à proteína GRP78 expressa em células prostáticas malignas DU145

Figura 10. Ligação do fago 4 (WDLAWMFRLPVG) à proteína GRP78 expressa em células prostáticas malignas DU145

Figura 11. Internalização dos fagos 1 e 4 nas células prostáticas malignas DU145 54 
Figura 12. Imunohistoquímica para detecção da ligação dos fagos a tumores prostáticos in vivo................................................. 56

Figura 13. Inibição da ligação dos fagos a metástases ósseas de tumores prostáticos humanos 


\section{Resumo}


ARAP, M.A. Estudo da proteína de choque térmico GRP78 para o desenvolvimento de um sistema de receptor-ligante para o câncer de próstata. São Paulo, 2003. Tese (Doutorado) - Faculdade de Medicina, Universidade de São Paulo.

Introdução: Apesar dos avanços nas técnicas de diagnóstico e tratamento, o câncer de próstata avançado ainda é uma condição letal. Terapêuticas mais eficazes são necessárias para reduzir as taxas de morbimortalidade associadas à doença. A Proteína-78 regulada pela glicose (GRP78), uma proteína de choque térmico envolvida na apresentação de antígenos, foi recentemente descrita como sendo um possível marcador molecular para o câncer de próstata. Ainda mais, a resposta imune a essa proteína mostrou correlação com o desenvolvimento de doença hormônioindependente e com pior sobrevida para a doença.

Objetivos: Neste estudo, avaliou-se a hipótese de que a GRP78 poderia ser usada como marcador molecular em câncer de próstata no desenvolvimento de um sistema de receptor-ligante, através do uso da tecnologia de apresentação de fagos.

Casuística e métodos: Inicialmente, foram clonados dois peptídeos que apresentam afinidade à proteína regulada pela GRP78 (os peptídeos WIFPWIQL e WDLAWMFRLPVG) no vetor fUSE5, criando-se fagos com capacidade teórica de ligação à mesma proteína. Posteriormente foi testada a capacidade de ligação desses fagos à GRP78 na membrana de células 
prostáticas malignas em solução, em xeno-tumores in vivo e em metástases ósseas de câncer de próstata humano.

Resultados: Demonstrou-se que ambos os fagos se ligam especificamente à GRP78 in vitro, em comparação à proteínas com seqüência semelhante (proteínas de choque térmico 70 e 90) e não semelhante (albumina sérica bovina). Em seguida, mostrou-se que esses fagos se ligam com afinidade pelo menos 30 vezes maior à células de câncer de próstata que o fago controle, e que os fagos são internalizados por essas células. Posteriormente, mostrou-se que os fagos rastrearam xeno-tumores prostáticos quando injetados in vivo num modelo animal de câncer de próstata. Finalmente, mostrou-se que os fagos ligam-se especificamente à GRP78 expressa em metástases ósseas de adenocarcinoma prostático humano.

Conclusões: Os fagos criados apresentam capacidade de ligação específica à GRP78 in vitro, em células em suspensão e in vivo. A estratégia e o sistema de receptor-ligante definidos no presente estudo podem ter implicacões relevantes no desenvolvimento de terapias dirigidas para o tratamento do câncer de próstata. 


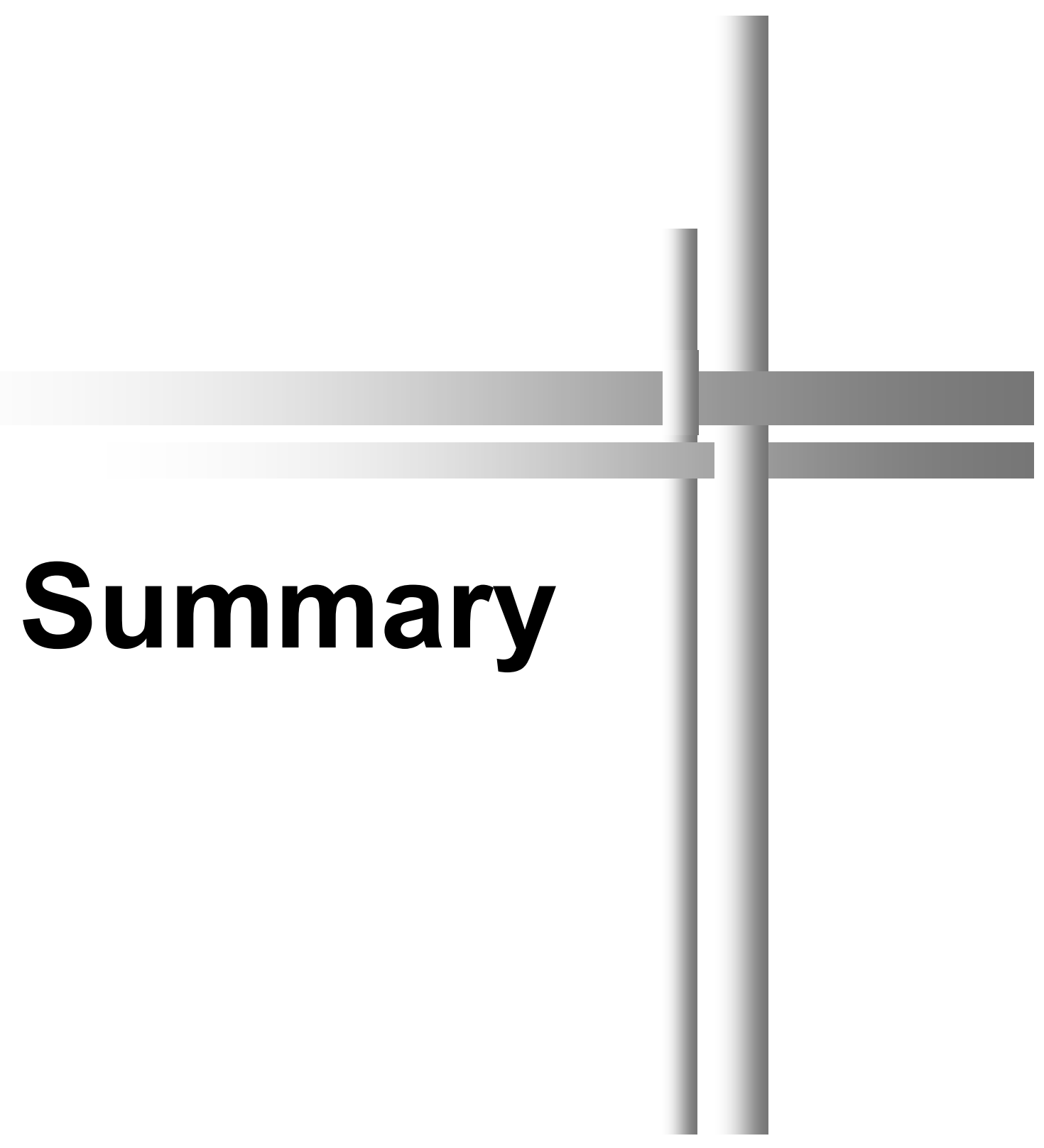


ARAP, M.A. Use of the heat-shock protein GRP78 for the development of a receptor-ligand system in prostate cancer. São Paulo, 2003. Tese (Doutorado) - Faculdade de Medicina, Universidade de São Paulo.

Introduction: Despite the advances in diagnosis and treatment, advanced prostate cancer remains a lethal condition. Improved methods of therapy are needed to reduce the morbidity and mortality rates associated with this disease. The Glucose-regulated protein-78 (GRP78), a stressresponsive heat-shock protein involved in antigen presentation, was recently described as a possible molecular marker for prostate cancer. Moreover, immune response against this protein was shown to have correlation with the development of androgen-independent prostate cancer and shorter overall survival.

Objectives: We hipothesized that GRP78 could be used as a molecular marker for prostate cancer in the development of a receptor-ligand system, by using phage display technology.

Patients and methods: We initially cloned two GRP78-targeting peptides (WIFPWIQL and WDLAWMFRLPVG) into a fUSE5-based phage. We then tested binding capacity of the phage to GRP78 in vitro, to GRP78 expressed in intact prostate cancer cell membranes, to a prostate cancer xenograft and to human bone metastases.

Results: We showed that both phage created bound specifically to GRP78 in vitro, in comparison to related (Heat-shock proteins 70 and 90) and 
unrelated control proteins (bovine serum albumin). Next, we showed that these phage bound at least 30 times more to prostate cancer cells than the control phage, and were also internalized into these cells. Both GRP78binding phage showed a strong homing in vivo to a human prostate cancer xenograft in a mouse model. Finally, we showed that both phage bound specifically to GRP78 expressed in human prostate cancer bone metastases.

Conclusions: Both phage are capable of binding specifically to GRP78 in vitro, in the context of intact prostate cancer cells and in vivo. The strategy and the ligand-receptor system we have defined in this study may have relevant implications in the development of targeted therapies for the treatment of prostate cancer. 


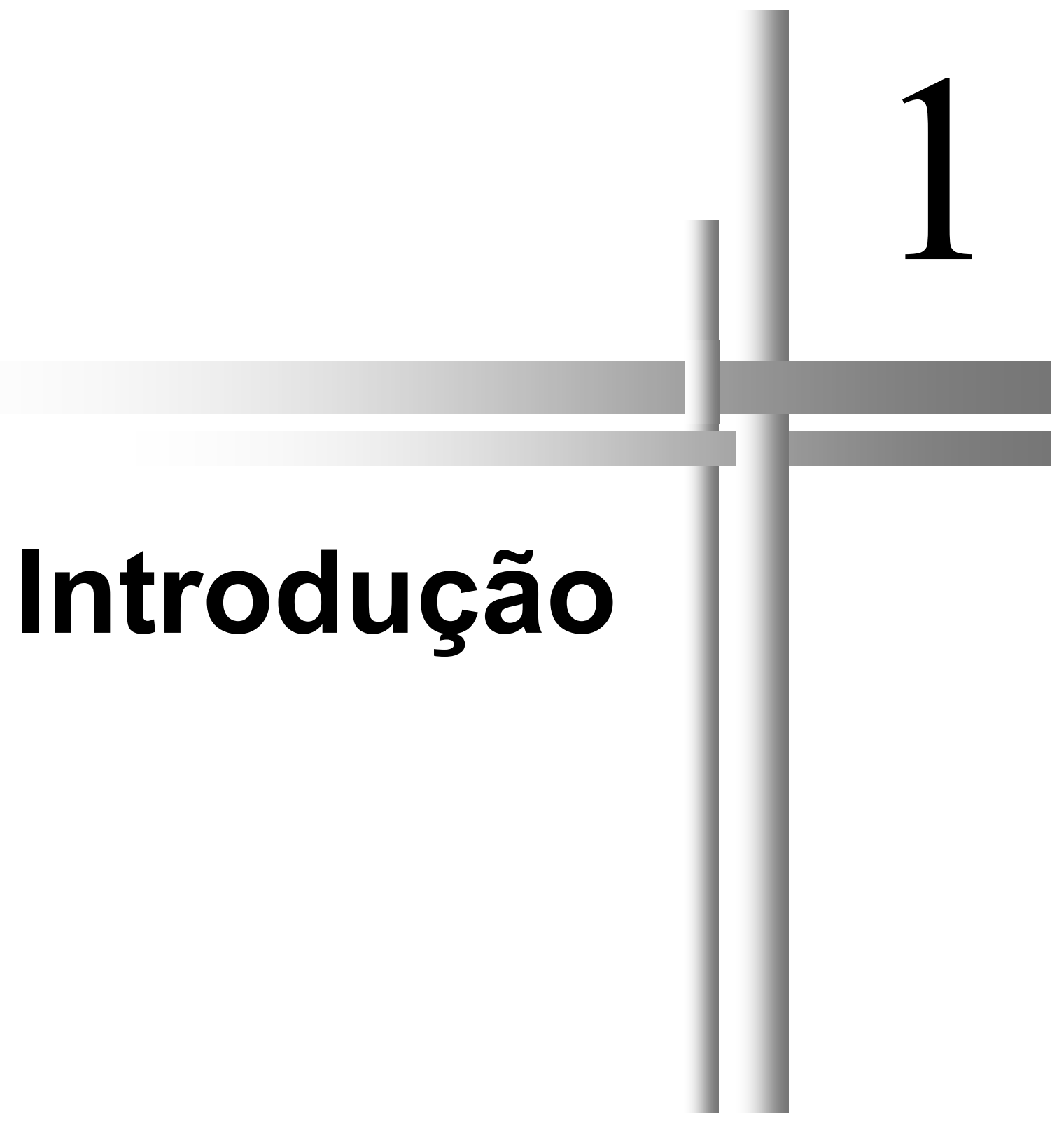




\section{Introdução}

O câncer de próstata é o quarto tipo mais comum de câncer diagnosticado em homens no mundo (REITER; DEKERNION, 2002), com taxa de incidência e mortalidade que variam significativamente de acordo com a região e a população estudada (GLOVER et al., 1998; MUIR et al., 1991; POST et al., 1998; REITER; DEKERNION, 2002; SANDBLOM et al., 2000). Desde o fim dos anos 80 e início dos anos 90, após a introdução do PSA (prostate specific antigen) para o rastreamento do câncer de próstata, houve um aumento na incidência geral da patologia (REITER; DEKERNION, 2002) e uma redução na idade média dos pacientes diagnosticados com a neoplasia. Avanços relacionados à biologia molecular, a identificação de fatores de risco, como história familiar e nível androgênico, e estudos relacionados a possíveis fatores preventivos, como dieta rica em licopenos, quimioprevenção com bloqueadores da $5 \propto$-redutase (COLTMAN et al, 1999) e utilização de retinóides (SLAWIN et al, 1993) permitiram um maior conhecimento da biologia e do comportamento fisiopatológico do câncer de próstata (REITER; DEKERNION, 2002).

Apesar da expansão dos conhecimentos epidemiológicos e biomoleculares sobre o câncer de próstata, ainda não sabemos predizer quais pacientes irão desenvolver patologia clinicamente significativa e quais permanecerão com tumor confinado ao órgão. Dessa forma, o tratamento da 
doença deve ser muitas vezes individualizado, tendo-se como base a expectativa e a qualidade de vida do paciente.

O câncer de próstata é patologia curável com cirurgia (HAN; PARTIN, 2002; JANI; HELLMAN, 2003; LEPOR, 2003), radioterapia (DATTOLI et al., 2003; JANI; HELLMAN, 2003) e outros métodos e combinações de métodos. Entretanto, esses tratamentos são efetivos para doença localizada e as eventuais recorrências tardias surgerem sub-estadiamento ou que o câncer de próstata pode metastatizar ainda em fases iniciais. Fica clara a necessidade de novas modalidades terapêuticas para o eventual controle da patologia em pacientes com doença extra-prostática já na ocasião do diagnóstico ou naqueles com tumor recorrente, uma vez que nesses casos a cura fica reduzida à grande minoria dos casos.

Com essa necessidade em mente, tivemos como finalidade no presente estudo desenvolver um sistema de receptor-ligante que possa permitir o rastreamento dirigido do câncer de próstata. A resposta imune contra a proteína-78 regulada pela glicose (Glucose regulated protein-78 GRP78) em pacientes com câncer de próstata avançado foi recentemente descrita (MINTZ et al., 2003) e mostrou correlação com o desenvolvimento de doença hormônio-independente e sobrevida reduzida relacionada ao tumor, sendo, por isso, o receptor molecular escolhido para esse estudo. 


\subsection{Câncer de próstata}

\subsubsection{Epidemiologia}

O câncer de próstata é a neoplasia mais comumente diagnosticada, e a segunda principal causa de morte relacionada ao câncer em homens nos Estados Unidos da América (AMERICAN CANCER SOCIETY, 2003). Segundo as estimativas referentes ao ano de 2003, aproximadamente 220.900 novos casos de câncer de próstata serão diagnosticados naquele país (AMERICAN CANCER SOCIETY, 2003), com cerca de 28.900 mortes relacionadas à doença no mesmo período.

Mundialmente, o câncer de próstata é a quarta neoplasia maligna mais comum em homens (REITER; DEKERNION, 2002), apresentando grandes variações de incidência e mortalidade de acordo com o país estudado (REITER; DEKERNION, 2002). Classicamente, países nórdicos apresentam altas taxas de incidência e mortalidade (BRASSO; IVERSON, 1999; POST et al., 1999), enquanto que países asiáticos como o Japão e a China tem uma das mais baixas taxas de incidência e mortalidade no mundo (MUIR et al., 1991; SHIMIZU et al., 1991).

Dados brasileiros mostram que, entre 1979 e 2000, a taxa de mortalidade por câncer de próstata aumentou de 3,73/100.000 para $8,98 / 100.000$, o que equivale a uma variação percentual relativa de $+141 \%$, revelando o papel do PSA na epidemiologia da doença (INCA, 2003). Para o 
ano de 2003, estima-se que o número de casos novos e de óbitos sejam, respectivamente, 35.240 e 8.230. Dessa forma, o câncer de próstata manterá a segunda maior taxa, tanto de mortalidade quanto de incidência, entre as neoplasias malignas em homens, superado apenas pelos tumores malignos de pele não melanoma e pelo câncer de pulmão (INCA, 2003).

\subsubsection{Fatores de risco}

Apesar das causas específicas da iniciação e progressão do câncer de próstata serem desconhecidas, evidências apontam para fatores genéticos e ambientais na evolução da doença. Até o momento, o fator de risco mais importante na patologia é a presença de andrógenos. Vários estudos tentaram determinar a relação exata entre os níveis de andrógenos e o risco de desenvolvimento da doença. Apesar da dificuldade de interpretação desses estudos, devida à fatores como variação circadiana do nível androgênico e dificuldade de se determinar a real exposição da próstata aos hormônios, estudos bem conduzidos determinaram resultados conflitantes. Alguns autores observaram relação entre risco de desenvolvimento de câncer de próstata e níveis aumentados de testosterona (GANN et al., 1996), enquanto outros não verificaram relação aparente em estudos prospectivos (BARRETT-CONNOR et al., 1990; GUESS et al., 1997). 
A distribuição familiar do câncer de próstata foi demonstrada em estudos de caso-controle, sugerindo que a genética pode ter papel importante em alguns casos (CARTER et al., 1992; STEINBERG et al., 1990). Homens com um parente de primeiro grau com câncer de próstata tem um risco duas vezes maior de desenvolver a doença que homens da mesma faixa etária, enquanto que no caso de dois ou três parentes de primeiro grau portadores da doença, o risco é respectivamente cinco e 11 vezes maior (REITER; DEKERNION, 2002).

Acredita-se que fatores ambientais também tem papel significativo no risco de desenvolvimento do câncer de próstata. A maior evidência disso vem de estudos de migração, que mostraram aumento na incidência da patologia na primeira geração de imigrantes do Japão e da China (MUIR et al., 1991; SHIMIZU et al., 1991). Entre os fatores até o momento estudados, a dieta rica em gorduras apresentou a maior correlação com a evolução da neoplasia (CLINTON et al., 1988; GIOVANNUCCI et al., 1993). Vários outros fatores como por exemplo atividade sexual (EWINGS; BOWIE, 1996), tabagismo (ADAMI et al., 1996), alcoolismo (POLLACK et al., 1984) e vasectomia (STANFORD et al., 1999) foram estudados, mas nenhum deles apresentou relação consistente com risco de desenvolvimento da doença. 


\subsubsection{Patologia}

\subsubsection{Tipos Histológicos}

O adenocarcinoma é o tipo histológico mais freqüente de câncer de próstata, sendo diagnosticado em mais de $90 \%$ dos casos. Outros tipos celulares são incomuns, como os carcinomas de células transicionais, que representam 1 a 4\% dos tumores prostáticos (SAWCZUK et al., 1985); os sarcomas, que representam 0,1 a $0,2 \%$; e os linfomas e leucemias, estes ainda mais raros (EPSTEIN, 2002).

\subsubsection{Classificação e Estadiamento}

A classificação de Gleason (GLEASON; MELLINGER, 1974) é a mais aceita e utilizada atualmente, sendo baseada no padrão glandular do tumor, verificado em pequena magnificação. Ambos os padrões primário (mais comum) e secundário (segundo mais comum) são identificados e para eles é determinada graduação que varia de 1 (um) a 5 (cinco), sendo um o mais diferenciado e cinco o mais indiferenciado. Como os dois padrões são importantes para a determinação do prognóstico, deu-se origem à soma dos graus de Gleason, denominada escore de Gleason, que portanto varia de dois a 10.

Os objetivos principais no estadiamento do câncer de próstata são predizer o prognóstico e facilitar a escolha da terapia, esta baseada 
principalmente na extensão da doença. O Sistema TNM (do inglês, TumorNodes-Metastasis), adotado pela AMERICAN JOINT COMMITTEE FOR CANCER STAGING (AJCC) em 1975 para o câncer de próstata, foi posteriormente modificado em 1992 e em 1997 pela União Internacional Contra o Câncer (UICC) e é o mais amplamente utilizado para o estadiamento da patologia na atualidade (CARTER; PARTIN, 2002) (Quadro 1).

Este sistema baseia-se na extensão do tumor primário, na presença de comprometimento linfonodal e na existência ou não de metástases em órgãos à distância. No presente estudo, utilizamos espécimes teciduais derivadas de metástases ósseas de pacientes com neoplasia estádio M1b, confirmadas patologicamente. A cura para pacientes com este estadiamento é muito rara, eles frequentemente apresentam doença hormônioindependente que geralmente responde mal à terapia e portanto são os pacientes que mais se beneficiariam com novas terapias dirigidas. 


\title{
Quadro 1. Classificação TNM para o câncer de próstata
}

\author{
(AJCC, 2002).
}

\section{Tumor Primário (T)}

- TX: Informação sobre tumor primário não disponível

- TO: Sem evidência de tumor primário

- T1: Tumor impalpável e não evidente por métodos de imagem

- T1a: Tumor encontrado em tecido removido por RTU; $5 \%$ ou menos do tecido ressecado é maligno com grau histológico $\leq 7$

- T1b: Tumor encontrado em tecido removido por RTU; > 5\% do tecido ressecado é maligno com grau histológico $>7$

- T1c: Tumor detectado por biópsia prostática devido à elevação n PSA

- T2: Tumor palpável confinado à próstata

- T2a: Tumor envolve apenas um lobo

- T2b: Tumor envolve mais que um lobo

- T3: Tumor palpável além da próstata

- T3a: Extensão extra-capsular unilateral

- T3b: Extensão extra-capsular bilateral

- T3c: Tumor invade vesículas seminais

- T4: Tumor é fixo e invade orgãos adjacentes (que não as vesículas seminais)

- T4a: Tumor invade colo vesical, esfíncter externo e/ou reto

- T4b: Tumor invade musculatura elevadora do ânus ou é fixo à parede pélvica

\section{Lifonodos regionais $(\mathrm{N})$}

- NX: Informação sobre lifonodos regionais não disponível

- NO: Ausência de metástases para lifonodos regionais

- N1: Metástases para um lifonodo regional único, $\operatorname{com} 2 \mathrm{~cm}$ ou menos de diâmetro

- N2: Metástases para um único lifonodo, com diâmetro entre $2 \mathrm{~cm}$ e $5 \mathrm{~cm}$; ou para lifonodos múltiplos, nenhum destes com mais de $5 \mathrm{~cm}$ de diâmetro

- N3: Metástases para lifonodos com mais de $5 \mathrm{~cm}$ de diâmetro

\section{Metástases à distância (M)}

- MX: Informação sobre metástases à distância não disponível

- MO: Ausência de metástases à distância

- M1: Metástases à distância

- M1a: envolvimento de linfonodos não regionais

- M1b: envolvimento de osso

- M1c: envolvimento de outros sítios à distância 


\subsubsection{Tratamento do câncer de próstata avançado}

O tratamento do câncer de próstata avançado (considerado como tumores T3NOMO, T4NOMO, N1 qualquer T e M1 qualquer T, de acordo com a classificação TNM) depende da idade do paciente, presença de comorbidades, sintomatologia e local de comprometimento extra-prostático. Os sintomas mais comuns em pacientes com câncer de próstata avançado decorrem do trato urinário ou de metástases ósseas. A paliação dos sintomas urinários (usualmente obstrução infra-vesical, dor e sangramento) pode ser conseguida com a ressecção trans-uretral, radioterapia externa, braquiterapia, hormonioterapia e até com a prostatectomia radical (PAULSON, 1987). Os resultados da prostatectomia radical para esse grupo de pacientes são muito inferiores quando comparados aos obtidos em pacientes com doeça localizada. A braquiterapia é tecnicamente muito difícil em tumores grandes e a hormonioterapia é geralmente indicada para pacientes com estádios mais avançados. Entretanto, o bloqueio hormonal e a radioterapia externa apresentam os melhores resultados para o controle da doença pélvica extra-prostática na maioria dos pacientes (BABAIAN et al., 1990; DEL REGATO et al., 1993, SAMANT et al., 2003). Entretanto, a cura é um evento raro em pacientes com tumores avançados, mesmo após resposta inicial significativa. Os efeitos colaterais mais comumente envolvidos com o controle local da doença são impotência, incontinência, enterite e cistite actínicas, sendo os últimos mais comuns no caso de radioterapia (LIM et al., 
1995; SCHELLHAMMER et al., 1986; WITJES et al., 1997; YAO; LU-YAO, 1999).

Para a paliação dos sintomas ósseos (usualmente dor e em casos mais graves fraturas patológicas), o bloqueio hormonal cirúrgico ou químico e a radioterapia são as melhores opções de tratamento. No entanto, a cura nesses casos á ainda mais rara e a freqüência de efeitos colaterais como ginecomastia, osteoporose e impotência (DANIELL, 1997; FOWLER et al., 2002) prejudicam a qualidade de vida e muitas vezes determinam a interrupção do tratamento. Portanto, fica clara a necessidade de aperfeiçoamento das modalidades atuais de tratamento e a criação de novas técnicas objetivando a cura de pacientes com câncer de próstata avançado.

\subsection{Tecnologia de apresentação de bacteriófagos}

Bacteriófagos (ou simplesmente fagos) pertencem a um grupo de vírus bacterianos com fita única de DNA envolta dentro de um longo capsídeo protéico cilíndrico (MARVIN, 1998; MARVIN et al., 1994) formado basicamente pela proteína codificada pelo gene VIII (pVIII) (Fig. 1). Os fagos da classe Fd (específicos para Escherichia coli com plasmídeo F) utilizados nesse estudo medem 6,5 nm de diâmetro e $930 \mathrm{~nm}$ de comprimento e não promovem a morte da bactéria hospedeira (WEBSTER, 2001). 


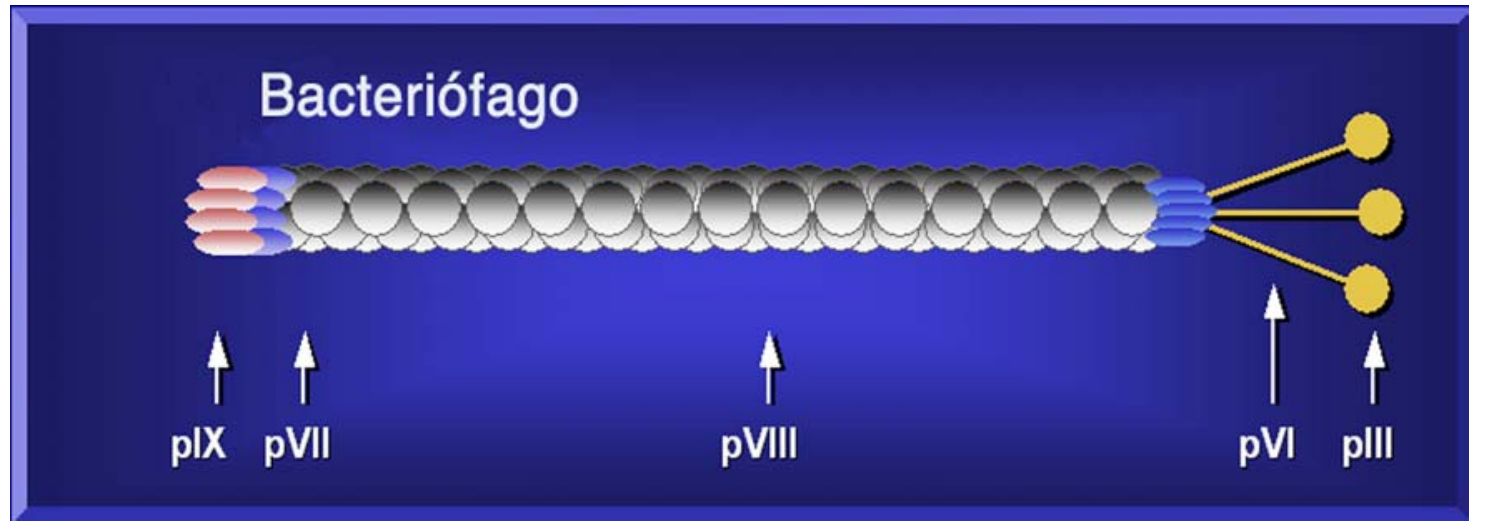

Figura 1. Esquema da estrutura do bacteriófago. Bacteriófagos (ou simplesmente fagos) pertencem a um grupo de vírus bacterianos com fita única de DNA envolta dentro de um longo capsídeo protéico cilíndrico. A proteína pVIII é a principal formadora do capsídeo protéico e a proteína pIII é a que utilizamos para a apresentação dos peptídeos no presente estudo. pVI, pVII e pXIX representam outras proteínas formadoras da partícula viral 
De um lado da partícula viral existem cinco moléculas codificadas pelos genes VII ( $p$ VII) e XIX ( $p X I X$ ) e na outra extremidade os fagos contém cinco moléculas protéicas codificadas por cada um dos genes III (pIII) e VI (pVI) (WEBSTER, 2001). A proteína pIII é a utilizada para a apresentação de peptídeos, que são a base das propriedades de ligação específica e rastreamento características dos fagos. O DNA correspondente aos peptídeos é inserido entre os sítios de restrição (SfI) do vetor fUSE5 indicados a seguir, após a remoção dos 14 pares de bases localizados entre os referidos sítios:

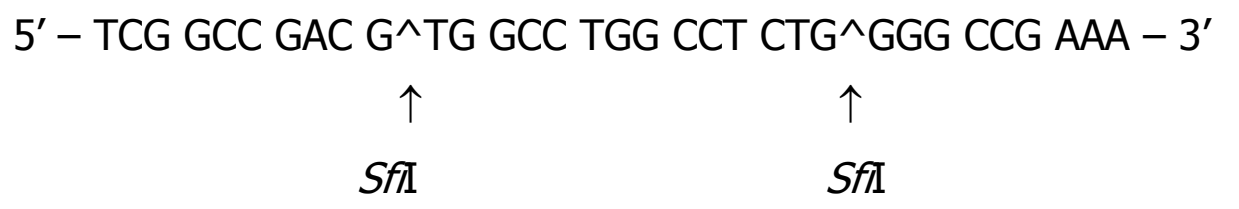

A tecnologia de apresentação de fagos foi descrita em 1985 (SMITH, 1985), e inicialmente desenvolvida para o mapeamento de sítios de ligação de anticorpos através do estudo da interação de bibliotecas de fagos (que expressam peptídeos randomizados) com imunoglobulinas imobilizadas. Essa tecnologia tornou-se uma potente ferramenta para o estudo de interações protéicas in vitro, em células em cultura e até in vivo (Fig. 2). É comumente utilizada para a seleção de peptídeos, anticorpos e proteínas recombinantes capazes de ligação específica (KOIVUNEN et al., 1999a; PASQUALINI; ARAP, 2002; SCOTT; SMITH，1990). Uma de suas grandes vantagens é a capacidade de detectar a disponibilidade de receptores em células em cultura e tecidos não só baseando-se em sua expressão, mas como também na acessibilidade a um probe circulante. 


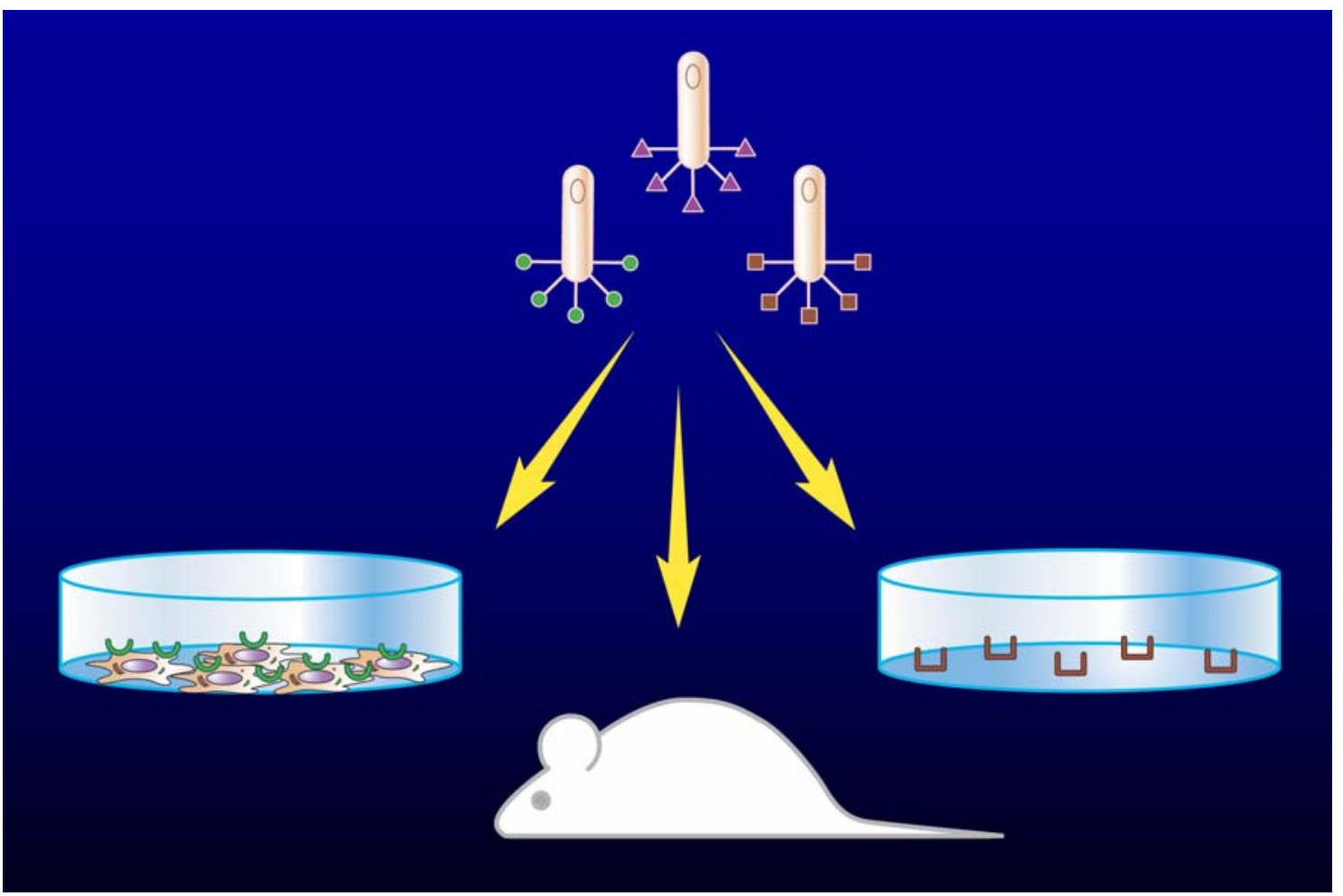

Figura 2. Utilização da tecnologia de apresentação de fagos. $A$ tecnologia de apresentação de fagos permitiu a identificação de pares receptores/ligantes desde ensaios in vitro a testes com células em cultura e in vivo. Interações protéicas identificadas in vitro podem ser testadas e validadas in vivo, mostrando a versatilidade do método. 
Bibliotecas com enorme variedade de permutações (até $10^{9}$ polipeptídeos) podem ser expressas na superfície das partículas do fago, permitindo o estudo de interações específicas entre esses peptídeos e seus receptores em cultura de células e tecidos in vitro. Desde sua criação, a tecnologia de apresentação de fagos permitiu a identificação in vitro de vários pares de receptores-ligantes, tanto para doenças malignas quanto benignas (ARAP et al., 2002b; ARDELT et al., 2003; KOIVUNEN et al., 1999a; KOLONIN et al., 2002). A utilização in vivo dessa tecnologia (Fig. 3) foi inicialmente descrita em 1996 (PASQUALINI; RUOSLAHTI, 1996), quando peptídeos com afinidade seletiva pelo endotélio do rim e do cérebro foram identificados em animais de experimentação. Este estudo deu o primeiro passo na seleção e identificação de marcadores endoteliais, e desde então a identificação de pares receptores/ligantes foi descrita para vários tecidos murinos, como rim, pulmões, pele, pâncreas, intestinos, útero, adrenal, retina e músculos. A seleção in vivo consiste inicialmente na injeção endovenosa da biblioteca de fagos (ou do fago previamente selecionado e amplificado) no animal de experimentação (usualmente o camundongo) devidamente anestesiado (KOLONIN et al., 2001). Os fagos devem permanecer circulando por tempo pré-determinado e o camundongo é então perfundido através de catéter inserido no ventrículo esquerdo. Deve ser realizada secção completa da veia cava inferior, para permitir a drenagem do líquido de perfusão. 


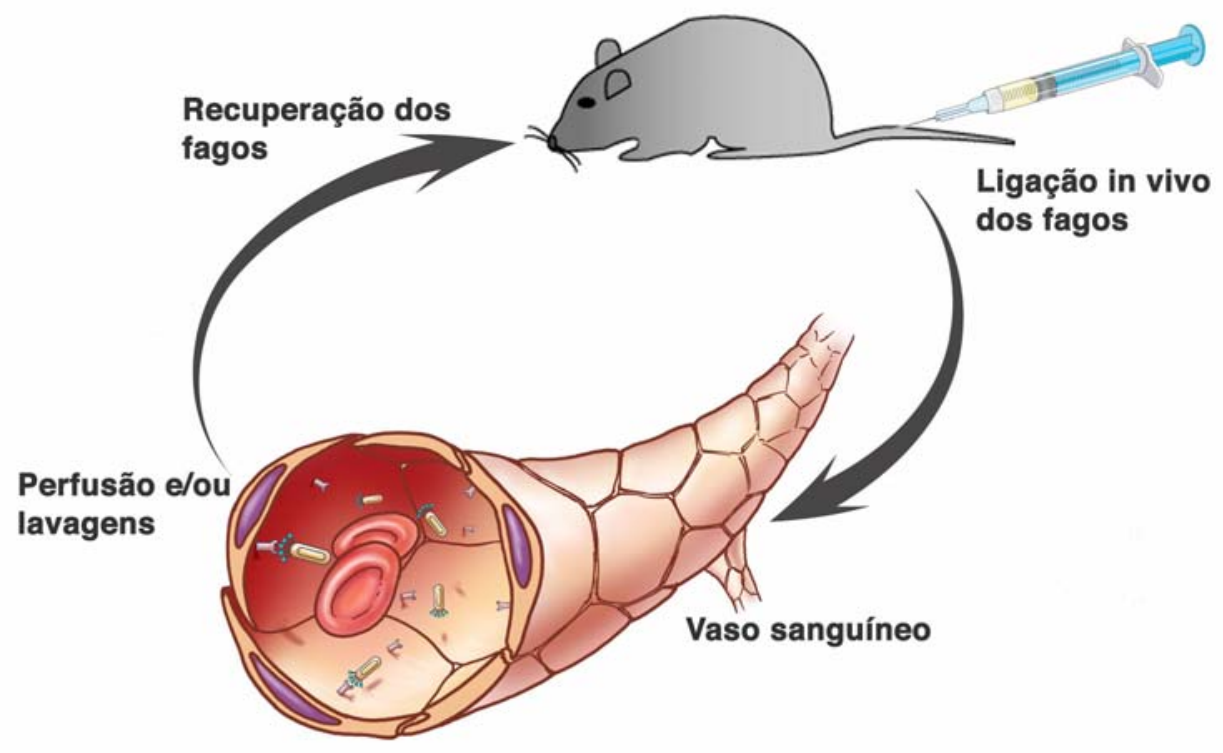

Figura 3. Esquema da utilização de fagos in vivo. $O$ rastreamento in vivo consiste inicialmente na injeção endovenosa dos fagos no animal de experimentação devidamente anestesiado. Os fagos devem permanecer circulando por período pré-determinado e o animal é então perfundido através de catéter inserido no ventrículo esquerdo. Deve ser realizada secção completa da veia cava inferior, para permitir a drenagem do líquido de perfusão. Após a perfusão, os órgãos de interesse são recuperados e processados para futuros ensaios. 
Quando planeja-se a coloração imunohistoquímica dos órgãos, como no caso do presente estudo, a perfusão é realizada com soluções fixadoras como paraformaldeido a $4 \%$ ou formol a $10 \%$. Após a perfusão, os órgãos de interesse são recuperados e fixados por $24 \mathrm{~h}$ em solução de paraformaldeido ou formol, de acordo com a solução utilizada para perfusão. A seletividade dos clones a serem testados a um órgão ou tecido específico é normalmente validada pela comparação individual da sua capacidade de ligação a outros órgãos e também a um fago controle que não contém peptídeo (PASQUALINI; ARAP, 2002). O processo de seleção in vivo traz consigo desafios devido à grande quantidade de variáveis que nele estão envolvidas. Apesar dessas dificuldades, o método apresenta importantes vantagens: primeiro, os peptídeos expressos no fago são identificados e testados através de avaliação funcional, que deve ser específica e ultrapassar os mecanismos naturais de degradação de moléculas e peptídeos não autólogos. Segundo, peptídeos que reconhecem proteínas de superfície plasmáticas e/ou inespecíficas são depletados do conjunto total de peptídeos. Finalmente, a seleção in vivo de peptídeos mostrou ser capaz de identificar receptores endoteliais expressos seletivamente em tumores (PASQUALINI et al., 2002). Esses receptores podem servir como marcadores tumorais moleculares, alvos para terapias dirigidas e até para o mapeamento da vasculatura normal e tumoral. Um dos principais marcadores moleculares em oncologia descobertos através da tecnologia de apresentação de fagos 
(MINTZ et al., 2003) foi a proteína-78 regulada pela glicose (glucoseregulated protein-78 - GRP78), descrita a seguir.

\subsection{As proteínas reguladas pela glicose (Glucose- regulated proteins - GRP)}

A resposta ao estresse celular é um mecanismo evolutivamente conservado, que permite às células responder à condições metabólicas e ambientais adversas. Essa resposta é representada, em nível molecular, pela indução da síntese de diferentes tipos de proteínas com função de proteção celular. O stress oxidativo, a exposição celular a metais pesados e situações patológicas como isquemia e reperfusão, inflamação e lesão tecidual estão associadas à expressão de proteínas de choque térmico (JOLLY; MORIMOTO, 2000). Chaperonas moleculares interagem com diversos substratos protéicos para auxiliar na adequada conformação tridimensional de proteínas recémformadas. Elas exercem papel importante durante o stress celular prevenindo a formação de proteínas com conformação tridimensional incorreta (JOLLY; MORIMOTO, 2000; LEWIN, 2000). Consequentemente, as proteínas de choque térmico auxiliam na recuperação celular após o stress reparando proteínas mal-formadas ou então promovendo sua degradação (JOLLY; MORIMOTO, 2000). Normalmente localizadas no retículo endoplasmático das células (LEE, 2001), as proteínas chaperonas podem também se localizar nos outros compartimentos celulares nos quais as proteínas adquirem a conformação final, como núcleo, mitocôndria e membrana plasmática 
(MELNICK; ARGON, 1995). As proteínas reguladas pela glicose (glucoseregulated proteins - GRP) são exemplos de chaperonas conhecidas.

\subsection{A proteína-78 regulada pela glicose (glucose- regulated protein-78 - GRP78)}

Inicialmente descrita (HAAS; WABL, 1983) e conhecida como proteína de ligação de imunoglobulinas (immunoglubulin-binding protein BiP), a GRP78 é a proteína da família das GRP mais bem caracterizada até o momento. Sua presença foi demonstrada no retículo endoplasmático de vários tipos celulares (LEE, 1992; MORIMOTO, 1993; MUNRO; PELHAM, 1986), sendo posteriormente, identificada também na membrana de células malignas (DELPINO; CASTELLI, 2002; SHIN et al., 2003; TRIANTAFILOU et al., 2001). Evolutivamente conservada desde organismos unicelulares a humanos, a GRP78 foi correlacionada a várias condições patológicas malignas e não malignas (FERNANDEZ et al., 2000; JAMORA et al., 1996; KATAYAMA et al., 1999; LITTLE et al., 1996; LIU et al., 1997).

Ensaios de superexpressão em culturas de células (LITTLE et al., 1994) e estudos de fragmentação de DNA (MIYAKE et al., 2000) evidenciaram que a GRP78 está diretamente envolvida na proteção celular contra apoptose. Apesar do mecanismo pelo qual as GRP atuam na prevenção de apotpose não estar totalmente esclarecido, estudos mostraram que uma GRP78 mutante, defectiva na hidrólise do ATP (requerido para a atividade de chaperona) perde seu mecanismo protetor (LIU et al., 1997), e 
que a expressão acentuada de GRP78 pode ter papel importante na proteção celular contra a depleção de cálcio do retículo endoplasmático (MIYAKE et al., 2000).

Numa grande variedade de tumores sólidos, biópsias de câncer humano e culturas de células malignas, os níveis de GRP78 estão elevados e correlacionam-se com malignidade (FERNANDEZ et al., 2000; LITTLE et al., 1994). Recentemente, a resposta imune contra GRP78 em câncer de próstata foi relacionada à presença de doença metastática (principalmente hormônio-independente) e à redução de sobrevida (MINTZ et al., 2003). Com base no grande conhecimento existente na literatura e nos resultados prévios de nosso laboratório (MINTZ et al., 2003) com a GRP78, essa proteína foi escolhida para a criação de um sistema de receptor-ligante que acreditamos no futuro poderá permitir o desenvolvimento da terapia dirigida para o câncer de próstata. 
Objetivos 


\section{Objetivos}

1. Criação de fagos que expressam peptídeos com capacidade de reconhecimento da GRP78.

2. Avaliar a capacidade dos fagos criados de reconhecer a GRP78 in vitro.

3. Avaliar a capacidade dos fagos criados de reconhecer a GRP78 no contexto de células prostáticas que expressam a proteína.

4. Avaliar a capacidade de internalização dos fagos pelas células prostáticas malignas.

5. Avaliar a capacidade dos fagos criados de reconhecer GRP78 em tumores prostáticos in vivo.

6. Avaliar a capacidade dos fagos criados de reconhecer a GRP78 em tumores prostáticos metastáticos 


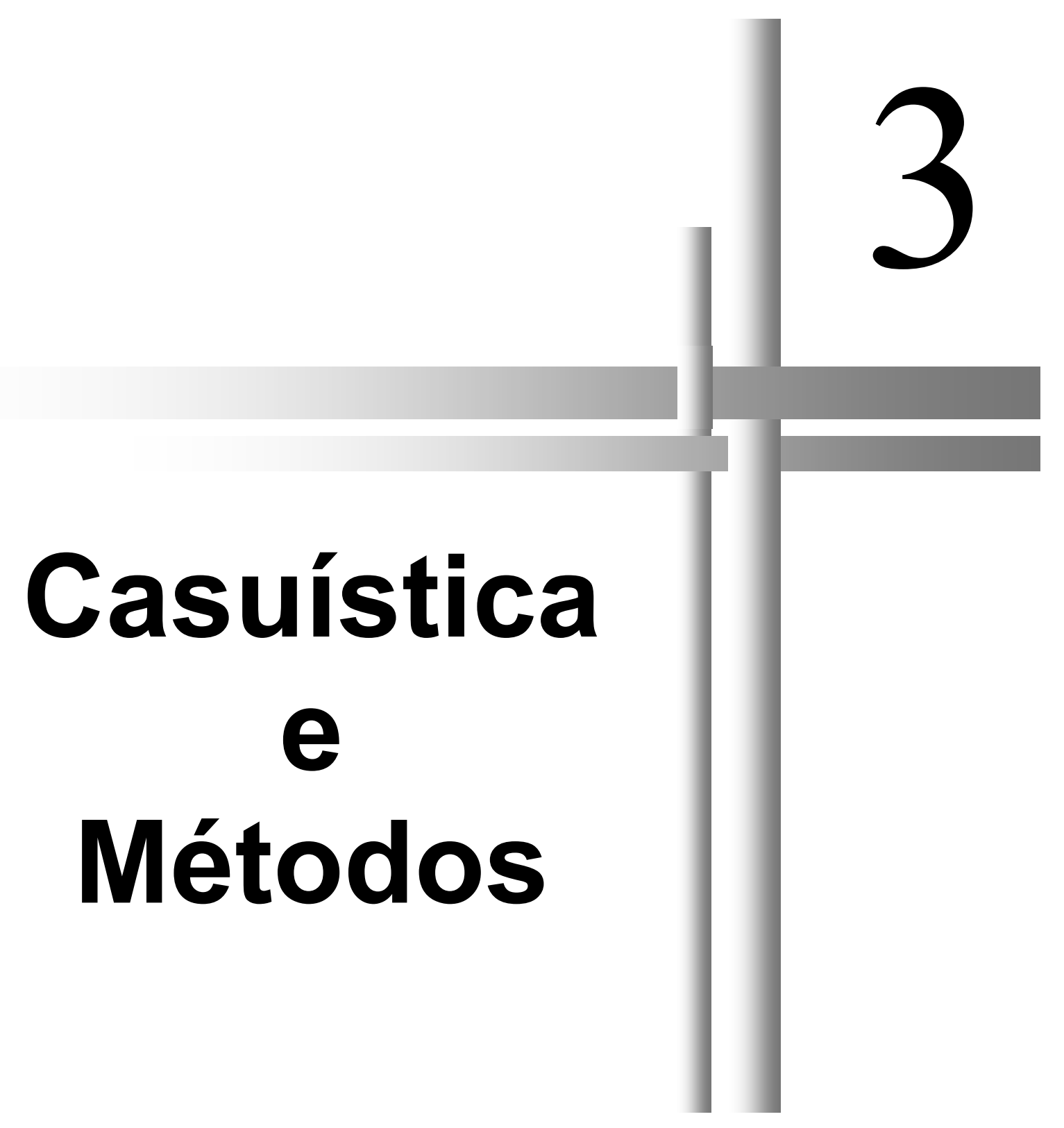




\section{Casuística e Métodos}

\subsection{Clonagem das seqüências de DNA selecionadas com afinidade à proteína GRP78 no vetor fUSE5}

O DNA correspondente a cinco peptídeos (quadro 2) com forte afinidade à proteína GRP78 (BLOND-ELGUINDI et al., 1993) foi clonado no vetor fUSE5. Inicialmente, $500 \mathrm{ng}$ dos oligonucleotídeos sintéticos correspondentes (Genemed Synthesis Inc., São Francisco, CA, EUA) foram convertidos a DNA de dupla fita utilizando-se amplificação através da técnica de PCR (polymerase chain reaction), onde foram empregados os primers (iniciadores 5' ou senso e 3' ou anti-senso) GTG AGC CGG CTG CCC (senso) e TTC GGC CCC AGC GGC (anti-senso). A reação de $P C R$ para esse par de primers (senso e anti-senso) foi realizada em solução contendo tampão de polimerase RedTaq 1X (Sigma, St. Louis, MO), 0,2mM de cada desoxinucleotídeo, 2,5 U de polimerase Taq-DNA (Promega, Madison, WI, EUA) e $2 \mu \mathrm{M}$ de cada primer num volume total de $20 \mu$. As condições da PCR constaram de uma fase inicial de dois minutos a $94^{\circ} \mathrm{C}$; 35 ciclos de 30 segundos a $94^{\circ} \mathrm{C}$, 30 segundos a $60^{\circ} \mathrm{C}$ e 30 segundos a $72^{\circ} \mathrm{C}$ seguidos de um período de extensão final a $72^{\circ} \mathrm{C}$ por cinco minutos, este último com o intuito de permitir a polimerização dos fragmentos incompletos. 
Quadro 2: Seqüêencia de DNA dos cinco peptídeos clonados no vetor fUSE5 (código de aminoácidos do IUB-IUPAC)



Os produtos das reações de PCR foram purificadas utilizando-se 0 conjunto de remoção de nucleotídeos (Qiagen Nucleotide Removal kit, QIAGEN, Hilden, Germany) de acordo com as orientações do fabricante e eluídos de cada coluna QIAquick através de duas lavagens com $50 \mu \mathrm{l}$ de água destilada. Os oligonucleotídeos foram clivados pela enzima $B g \rrbracket$ por duas horas a $37^{\circ} \mathrm{C}$, repurificados utilizando-se o mesmo conjunto de remoção de nucleotídeos (QIAGEN, Hilden, Germany) e ligados ao vetor fUSE5 (SMITH; SCOTT, 1993) (previamente clivado pela enzima SfI por duas horas a $50^{\circ} \mathrm{C}$ ). Os plasmídeos foram então inseridos por eletroporação na bactéria Escherichia coli MC1061 (KOIVUNEN et al., 1999a) e, após adição de $1 \mathrm{ml}$ de meio SOC (Invitrogen Corporation, Carlsbad, CA, EUA), a suspensão 
bacteriana foi mantida em cultura por uma hora a $37^{\circ} \mathrm{C}$ e alíquotas foram espalhadas em placas de ágar Luria-Bertani (LB) contendo $40 \mu \mathrm{g} / \mathrm{ml}$ de tetraciclina e $100 \mu \mathrm{g}$ de kanamicina. Foi então realizada amplificação das colônias bacterianas através de PCR, e as amostras foram enviadas para seqüenciamento automático (HUANG, 1999).

Uma vez confirmadas as sequências dos fagos recém-clonados, foi realizada amplificação dos clones (PASQUALINI et al., 2001; SMITH; SCOTT, 1993). Inicialmente, $200 \mu \mathrm{l}$ de suspensão bacteriana de Escherichia coli em fase de crescimento logarítmico (densidade ótica de 1,5 a 2 a $600 \mathrm{~nm}$ ) foram infectados separadamente com $1 \mu \mathrm{l}$ de cada clone por 30 minutos em temperatura ambiente. Em seguida, cada volume de $200 \mu \mathrm{l}$ foi mantido em cultura em $500 \mathrm{ml}$ de meio Luria-Bertani (LB) suplementado com $40 \mu \mathrm{g} / \mathrm{ml}$ de tetraciclina e $100 \mu \mathrm{g} / \mathrm{ml}$ de kanamicina por $12 \mathrm{~h}$ a $37^{\circ} \mathrm{C}$, centrifugado a $6000 \mathrm{rpm}$ por 15 minutos a $4^{\circ} \mathrm{C}$ e o sobrenadante foi recolhido em frasco estéril. Para cada $100 \mathrm{ml}$ de sobrenadante recolhido foram adicionados $15 \mathrm{ml}$ de polietileno glicol (PEG) suplementado com cloreto de sódio e o frasco foi mantido a $4^{\circ} \mathrm{C}$ por no mínimo duas horas para a precipitação dos fagos. Em seguida a suspensão de fagos foi centrifugada a $15000 \mathrm{~g}$ por 30 minutos a $4^{\circ} \mathrm{C}$ e o grânulo (pellet) foi lavado com $500 \mu \mathrm{l}$ de solução salina tamponada com fosfato (phosphate buffered saline - PBS), centrifugado a $13000 \mathrm{~g}$ por 10 minutos e resuspenso em $200 \mu \mathrm{l}$ de PBS. Cada fago clonado, juntamente com o fago controle negativo (Fd-tet), foi titulado através de diluições seriadas e infecção de suspensões bacterianas de Escherichia coli, cepa K91kan em crescimento logarítmico (densidade óptica de 2 a $600 \mathrm{~nm}$ ), as 
quais foram em seguida espalhadas em placas de ágar Luria-Bertani (LB) contendo $40 \mu \mathrm{g} / \mathrm{ml}$ de tetraciclina e $100 \mu \mathrm{g} / \mathrm{ml}$ de kanamicina (MINTZ et al., 2003; PASQUALINI et al., 2001; SMITH; SCOTT, 1993). As placas foram incubadas por uma noite a $37^{\circ} \mathrm{C}$ e o número de unidades transducentes (UT) de fagos foram contados em três placas (triplicatas) para cada diluição para cada micropoço, totalizando 6 placas analisadas para cada proteína estudada.

\subsection{Testes de ligação dos fagos in vitro}

As proteínas GRP78 (glucose regulated protein-78), HSP70 (heatshock protein 70) e HSP90 (heat-shock protein 90) foram obtidas comercialmente (Stressgen, Victoria, Canada). Essas proteínas, juntamente com albumina sérica bovina (bovine serum albumin - BSA) foram adsorvidas em micropoços (microwells ou wells) de placas plásticas contendo 96 micropoços tipo Linbro (ICN Biomedicals, Aurora, Ohio, EUA) por $12 \mathrm{~h}$ a $4^{\circ} \mathrm{C}$. $50 \mu \mathrm{l}$ de cada proteína foi adsorvida (numa concentração de $10 \mu \mathrm{g} / \mathrm{ml}$ ) em dois micropoços na mesma placa plástica, tendo-se o cuidado de intercalar micropoços vazios entre os ocupados pelas diferentes proteínas, dessa forma evitando-se contaminação intra-estudo. Os micropoços foram lavados duas vezes com PBS, bloqueados com PBS contendo 3\% de BSA por uma hora a temperatura ambiente, e incubados com $10^{9}$ unidades transducentes (UT) de fago em $50 \mu \mathrm{l}$ de solução de PBS contendo $1,5 \%$ de BSA. Após duas horas em temperatura ambiente, os micropoços foram lavados 12 vezes com PBS e os fagos ligados às proteínas nos micropoços foram recuperados através de 
infeç̧ão com suspensão bacteriana de Escherichia coli (K91kan), conforme descrito anteriormente (KOIVUNEN et al., 1999b; KOLONIN et al., 2001; PASQUALINI; ARAP, 2002; PASQUALINI et al., 2001) e no item 3.1.

\subsection{Inibição da ligação dos fagos in vitro com os peptídeos sintéticos}

Concentrações progressivamente maiores dos peptídeos sintéticos correspondentes aos fagos 1 e 4 foram utilizadas para os testes de inibição de ligação dos fagos. Todos os peptídeos foram solubilizados na mesma concentração em água destilada contendo $10 \%$ de dimetilsulfóxido e posteriormente foram diluídos para a realização dos testes. A adsorção das proteínas, lavagem dos micropoços e o bloqueio dos sítios de ligação inespecíficos das placas foram realizados da mesma forma que a descrita no item 3.2. Em seguida, concentrações progressivamente crescentes dos peptídeos sintéticos (Genemed Synthesis, Inc., São Francisco, CA, EUA) correspondentes aos fagos 1 e 4, e do peptídeo controle CARAC (AnaSpec Inc., San Jose, CA, EUA), foram adicionadas em diferentes micropoços antes da adição dos respectivos fagos. Os peptídeos sintéticos foram mantidos por uma hora nos micropoços, sendo então adicionados os fagos, de forma que cada um deles teve o bloqueio de sua ligação à proteína GRP78 testado com o peptídeo correspondente e com o peptídeo controle em dois micropoços. Após a adição dos peptídeos sintéticos e dos fagos, a lavagem dos micropoços, recuperação dos fagos ligados à proteína GRP78, as diluições 
bacterianas seriadas e a contagem das UT foi realizada da mesma forma que no item 3.2.

\subsection{Teste de ligação dos fagos à células prostáticas malignas DU145}

Para o estudo da interação dos fagos com as células prostáticas DU145 (MICKEY et al., 1977), foi utilizada técnica denominada BRASIL (Biopanning and Rapid Analysis of Selective Interactive Ligands), descrita previamente no nosso laboratório (GIORDANO et al., 2001). A linhagem celular derivada de adenocarcinoma prostático DU145 foi obtida da American Type Culture Collection (Rockville, MD, EUA). As células foram cultivadas em meio DMEM (Dulbecco's Modified Eagle Media) suplementado com soro bovino fetal a $10 \%$, penicilina $(100 \mathrm{U} / \mathrm{ml})$ e estreptomicina $(100 \mu \mathrm{g} / \mathrm{ml})$ em uma atmosfera umidificada com $5 \%$ de $\mathrm{CO}_{2}$ a uma temperatura estável de $37{ }^{\circ} \mathrm{C}$. As células foram mantidas em cultura até confluência de $70 \%$, destacadas do frasco de cultura com solução de $5 \mathrm{mM}$ de ácido etileno diamino tetracético (EDTA) e suspensas em DMEM contendo 1\% de BSA a uma concentração de quatro milhões de células por ml. A suspensão celular foi incubada com $10^{9}$ UT de cada um dos fagos 1 , 4 e controle (Fd-tet) em tubo Eppendorf de 1,5 ml, mantido em rotação constante. A fim de minimizar os eventos pós-ligação, tais como internalização mediada pelo receptor, as células e o meio foram mantidos no gelo. Após duas horas, a suspensão fago-célula foi lavada uma vez com DMEM, gentilmente transferida para a

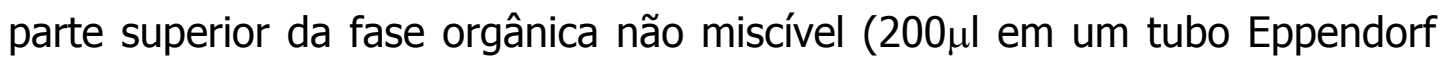


com capacidade para $400 \mu \mathrm{l}$ ) e centrifugada a $10.000 \mathrm{~g}$ por $10 \mathrm{~min}$ a $4^{\circ} \mathrm{C}$. A combinação utilizada para a fase orgânica foi dibutilftalato:ciclo-hexano (9:1 $[\mathrm{v}: \mathrm{v}] ; \mathrm{d}=1.03 \mathrm{gml}^{-1}$ ). $\mathrm{O}$ tubo foi congelado instantaneamente em nitrogênio líquido, a parte inferior do tubo foi cortada e o pellet fago-célula foi transferido para um tubo novo; essa técnica otimizada de congelamentocorte (GIORDANO et al., 2001) evita contaminação cruzada com o fago remanescente na fase aquosa. Os fagos ligados às células foram recuperados através da adição de $100 \mu \mathrm{l}$ de suspensão de Eschericia coli cepa K91kan em fase logarítmica, conforme descrito anteriormente (ARDELT et al., 2003; GIORDANO et al., 2001). Diluições seriadas da suspensão bacteriana foram espalhadas em placas de ágar Luria-Bertani (LB) contendo $40 \mu \mathrm{g} / \mathrm{ml}$ de tetraciclina e $100 \mu \mathrm{g}$ de kanamicina. As placas foram incubadas por uma noite a $37^{\circ} \mathrm{C}$ e o número de UT de fagos foram contados em três placas (triplicatas) para cada diluição, totalizando 6 placas para cada interação fagocélula.

\subsection{Inibição da ligação dos fagos às células prostáticas malignas DU145}

Com o objetivo de avaliar a especificidade da ligação dos fagos à proteína GRP78, foi utilizado anticorpo policlonal IgG anti-GRP78 (Santa Cruz Biotechnology, Santa Cruz, CA, EUA), a proteína GRP78 em solução (Stressgen, Victoria, Canada), e os peptídeos sintéticos cognatos aos fagos (Genemed Synthesis Inc., São Francisco, CA, EUA) para ensaios de inibição da ligação dos fagos às células. Resumidamente, a cultura das células DU145 
e o destacamento das mesmas do frasco foram realizados como no item 3.4. Em seguida, a cada um dos tubos foi adicionado um dos seguintes: anticorpo anti-GRP78 (diluição 1:50), GRP78 $(100 \mu \mathrm{g} / \mathrm{ml})$ ou o peptídeo cognato ao fago $(500 \mu \mathrm{g} / \mathrm{ml})$ e mantido em rotação por uma hora. $O$ fago foi então adicionado e mantido por duas horas na solução. A partir daí, a lavagem com DMEM, a passagem para o tubo contendo a fase inorgânica não miscível, a centrifugação dos tubos e a recuperação bacteriana e contagem dos fagos foi realizada da mesma forma que no item 3.4.

\subsection{Internalização dos fagos pelas células prostáticas malignas DU145}

Foi avaliada a capacidade de internalização dos fagos pelas células DU145 com um ensaio de internalização celular, após a confirmação de que os fagos ligam-se de forma específica à proteína GRP78 expressa na membrana das células DU145. As células prostáticas e as células controle (derivadas de câncer de mama, denominadas MDA-MB-435) (PRICE et al., 1990) foram cultivadas em lâminas de câmara de tecido Lab-Tek II Chamber Slide System (Nalge Nunc International Corp., Naperville, IL, EUA). Para esse ensaio, foram utilizados os fagos 1, 4, o fago controle negativo (Fd-tet), e finalmente o fago controle positivo, que expressa o motivo CDCRGDCFC (chamado RGD-4C) de ligação à $\alpha v$-integrina. O RGD-4C rastreia as integrinas que são expressas por essas células e esses receptores são bem caracterizados quanto a sua capacidade de internalização (KOIVUNEN et al., 
1999c). Duas câmaras com cada uma das linhagens celulares foram incubadas com $10^{9}$ UT de cada um dos fagos em solução de DMEM com $1 \%$ BSA por quatro horas a $37^{\circ} \mathrm{C}$. As células foram lavadas cinco vezes com PBS, posteriormente tratadas com solução de glicina $(\mathrm{NaCl} 500 \mathrm{mM} / \mathrm{glicina} 50 \mathrm{mM}$, pH 2,3) para remoção do fago não internalizado acoplado à membrana (quatro lavagens, três minutos cada lavagem). Para se evitar danos aos fagos devidos ao pH da solução de glicina, as células foram lavadas três vezes com PBS e posteriormente fixadas a $4^{\circ} \mathrm{C}$ com paraformaldeido a $4 \%$ em PBS. As células foram então lavadas com PBS, permeabilizadas com Triton X-100 (Sigma Chemical Group, St. Louis, MO, EUA) a 0,2\% e novamente lavadas com PBS. Uma das câmaras foi incubada com RGD-4C e tratada com PBS como controle de permeabilização. Após bloqueio em temperatura ambiente dos sítios de ligação inespecíficos com solução de BSA a $1 \%$ em PBS por duas horas, os fagos internalizados foram detectados com um anticorpo de coelho policlonal antibacteriófago (Amersham, Piscataway, NJ, EUA) diluído a 1:200 em solução de BSA 1\% em PBS. Após cinco lavagens com PBS, foi adicionado o anticorpo secundário IgG anti-coelho conjugado com Cy3 (Jackson Immunoresearch Laboratories Inc., West Grove, PA, EUA) diluído a 1:200 em solução de BSA 1\% em PBS e mantido por uma hora em temperatura ambiente. Novamente as células foram lavadas com PBS, fixadas em solução de paraformaldeido a 4\% em PBS por cinco minutos e, finalmente, as câmaras foram montadas com o conjunto Vectashield (Vector Laboratories Inc., Burlingame, CA, EUA). 


\subsection{Estabelecimento dos modelos animais de câncer de próstata}

Camundongos macho atímicos foram obtidos comercialmente (Harlan-Sprague-Dawley, Indianapolis, IN, EUA). Todos os experimentos foram realizados após aprovação do comitê interno de utilização e cuidado de animais (Institutional Animal Care and Use Committee - IACUC) do M.D. Anderson Cancer Center, Universidade do Texas, EUA. Os xeno-enxertos prostáticos foram estabelecidos no tecido celular subcutâneo torácico ventral dos camundongos através de injeção de $10^{6}$ células humanas prostáticas malignas tipo DU145 (MICKEY et al., 1977) em solução de DMEM livre de soro, num volume total de $200 \mu$ l. Os camundongos foram acompanhados semanalmente e verificou-se que 8 semanas após a injeção das células os tumores formados apresentavam dimensões que variavam de 1 a $1,3 \mathrm{~cm}$ (figura 2). De 12 a 16 semanas após a injeção das células, os tumores já apresentavam áreas de necrose e dimensões não permitidas pelo IACUC. Todos os animais utilizados no ensaio de ligação dos fagos in vivo apresentavam tumores variando entre 1 e 1,3 cm e as injeções foram todas realizadas pelo mesmo pesquisador. 


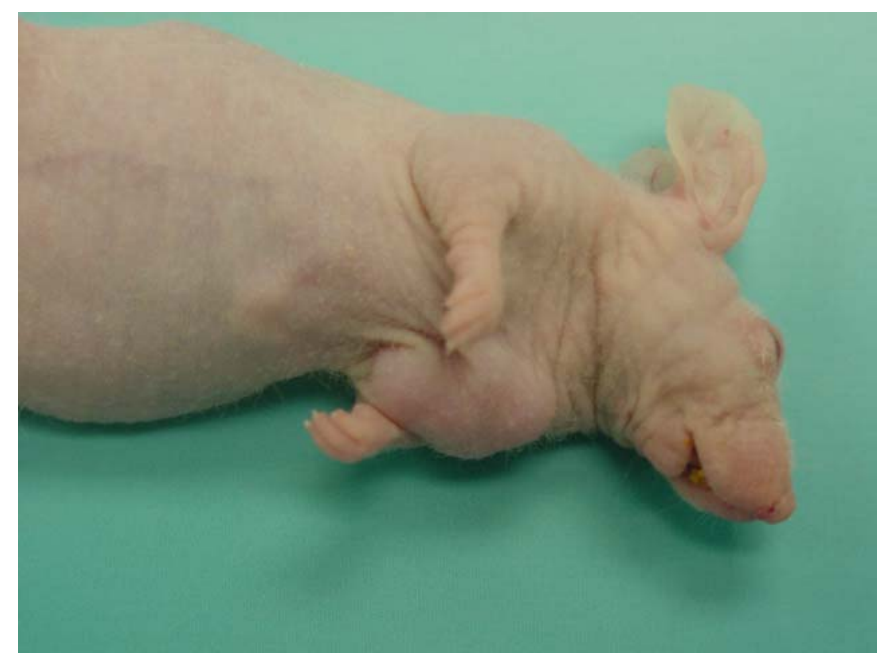

Figura 4. Exemplo de xeno-enxerto de adenocarcinoma de próstata em camundongo tipo "nude". No camundongo anestesiado, identifica-se o enxerto tumoral em face ventral do tórax, com aproximadamente $1,3 \mathrm{~cm}$ no maior diâmetro. Todos os modelos animais apresentavam tumores semelhantes aos do representado na figura. 


\subsection{Ensaio de rastreamento dos tumores prostáticos in vivo}

O ensaio de rastreamento in vivo foi realizado conforme descrito anteriormente (ARAP et al., 2002a; ARAP et al., 1998; KOIVUNEN et al., 1999b; PASQUALINI et al., 2001; PASQUALINI; RUOSLAHTI, 1996; TREPEL et al., 2002). Resumidamente, os animais foram anestesiados através de injeção intra-peritoneal de $500 \mu \mathrm{l}$ de um composto denominado Avertin, constituído por 2,5g de 2,2,2-tribromoetanol e $5 \mathrm{ml}$ de 2-metil-2 -butanol em $200 \mathrm{ml}$ de água destilada. Uma vez anestesiados, animais com tumores de dimensões similares receberam injeção intravenosa (realizada na veia da cauda) de $10^{9}$ UT dos fagos 1 , 4, controle negativo (Fd-tet) e controle positivo (RGD-4C) em DMEM. Cada fago foi injetado em três animais e permaneceu circulando por $24 \mathrm{~h}$. Após esse período, os animais foram novamente anestesiados (da mesma forma que a descrita acima) e foi realizada incisão ventral mediana, com exposição de cavidades torácica e abdominal. Foi então realizada perfusão intra-cardíaca com $20 \mathrm{ml}$ de paraformaldeido a 4\% em PBS (para a remoção de eritrócitos, redução de ruído e fixação adequada das estruturas vasculares) e os tumores e órgãos controle negativo (cérebro) e controle positivo (fígado), foram ressecados e fixados por $12 \mathrm{~h}$ a $4^{\circ} \mathrm{C}$ em paraformaldeido diluído a $4 \%$ em PBS. Em seguida, os órgãos foram embebidos em parafina e mantidos dessa forma para futuros ensaios de imunohistoquímica. O fígado foi utilizado como 
controle positivo uma vez que a eliminação dos fagos é realizada nesse órgão (PASQUALINI; ARAP, 2002).

\subsection{Imunohistoquímica para detecção de fagos nos modelos animais de xeno-tumores prostáticos}

Anticorpos anti-bacteriófago desenvolvidos em coelhos (Sigma Chemical Group, St. Louis, MO, EUA) e o conjunto de peroxidase LSAB+ (DAKO, Carpinteria, CA, EUA) foram utilizados para detectar a presença dos fagos nas amostras dos órgãos normais e nos tumores com o emprego de técnicas habituais de imunohistoquímica. Resumidamente, os blocos de parafina previamente obtidos contendo as amostras a serem analisadas foram microtomizados obtendo-se secções de $4 \mu \mathrm{m}$ de espessura, as quais foram montadas em lâminas de microscopia e postas para secar em temperatura ambiente por 24 horas. Após a desparafinização e rehidratação (com xileno e gradiente alcoólico - etanol 100\%, 95\% e 80\%), as seç̧ões foram tratadas com peróxido de hidrogênio $\left(\mathrm{H}_{2} \mathrm{O}_{2}\right)$ a $2 \%$ em metanol por 20 minutos, visando à inativação da peroxidase endógena. A recuperação do antígeno foi feita por imersão das lâminas em solução de citrato tamponada (LSAB+, DAKO, Carpinteria, CA, EUA), seguida de aquecimento em forno de microondas por sete minutos em potência total e 13 minutos em potência de $40 \%$. Após bloqueio de eventuais ligações protéicas inespecíficas com o bloqueador protéico do conjunto LSAB+ por 15 minutos, as secções foram incubadas por uma hora em câmara úmida com anticorpo IgG primário de 
coelho (Sigma Chemical Group, St. Louis, MO, EUA) em uma diluição de 1:500 em solução de diluição de anticorpos do conjunto LSAB+ (DAKO). As seç̧ões foram lavadas com Tris $20 \mathrm{mM}, \mathrm{NaCl} 150 \mathrm{mM}$ e solução de Tween 20 (TBST, DAKO, Carpinteria, CA, EUA) a 0,05\% (ph 7,8), para em seguida serem incubadas com o anticorpo secundário anti-coelho conjugado à peroxidase K400211 (DAKO EnVision, Carpinteria, CA, EUA) por 30 minutos. A imunohistoquímica foi realizada utilizando-se o método da peroxidade com diaminobenzidina como cromógeno (DAKO, Carpinteria, CA, EUA), seguida de hematoxilina como corante complementar e da desidratação dos tecidos em gradiente alcoólico e xileno. Em relação à imunoreatividade à presença dos fagos, tanto os órgãos normais quanto os tumores foram classificados em: positivas (quando todo o tecido presente na amostra se mostrou imunoreativo), negativas (nenhuma região do tecido apresentou imunoreatividade) ou parciais (regiões com e sem imunoreatividade mesclados na mesma lâmina).

\subsection{Pacientes e espécimes teciduais}

As amostras de metástases ósseas de tumores prostáticos analisadas no presente estudo foram provenientes de seis pacientes submetidos à biópsia cirúrgica das lesões no Hospital das Clínicas da Faculdade de Medicina da Universidade São Paulo (Tabela 1). É importante ressaltar que nenhum paciente foi submetido a qualquer procedimento com 
o objetivo de coletar material para pesquisa. Todos os espécimes humanos foram obtidos a partir de blocos de parafina dos arquivos do Departamento de Anatomia Patológica do Hospital das Clínicas da Faculdade de Medicina da Universidade de São Paulo após o consentimento do Comitê de Ética da referida Instituição, e analisados no laboratório do Departamento de Oncologia Gênito-Urinária do M. D. Anderson Cancer Center, Universidade do Texas (UT-MDACC).

Tabela 1 - Sumário dos dados demográficos dos pacientes com adenocarcinoma de próstata metastático.

\begin{tabular}{|c|c|c|c|c|}
\hline Paciente & Idade & PSA & Relatório anátomo-patológico (local de ressecção) & $\begin{array}{l}\text { Número } \\
\text { de blocos }\end{array}$ \\
\hline 1 & 86 & 158 & $\begin{array}{l}\text { Carcinoma metastático, compatível com neoplasia } \\
\text { primária de próstata (cabeça de fêmur) }\end{array}$ & 1 \\
\hline 2 & 66 & 54,5 & $\begin{array}{l}\text { Carcinoma metastático, compatível com neoplasia } \\
\text { primária de próstata (cabeça e colo de fêmur) }\end{array}$ & 1 \\
\hline 3 & 76 & 235 & $\begin{array}{l}\text { Carcinoma metastático, compatível com neoplasia } \\
\text { primária de próstata (cabeça e colo de fêmur) }\end{array}$ & 2 \\
\hline 4 & 78 & 22,1 & $\begin{array}{l}\text { Carcinoma metastático com colo ósteo cartilaginoso } \\
\text { sugestivo de origem prostática (coluna vertebral) }\end{array}$ & 1 \\
\hline 5 & 60 & 117 & $\begin{array}{l}\text { Carinoma metastático fortemente sugestivo de } \\
\text { origem prostática (coluna vertebral) }\end{array}$ & 2 \\
\hline 6 & 87 & 116 & $\begin{array}{c}\text { Adenocarcinoma metastático em tecido ósseo } \\
\text { (artroplastia de quadril) }\end{array}$ & 2 \\
\hline
\end{tabular}

Os blocos parafinados contendo as amostras teciduais foram microtomizados para a obtenção de secções de $4 \mu \mathrm{m}$ de espessura, as quais foram montadas em lâminas de microscopia e postas para secar em temperatura ambiente por 24 horas. Todas as amostras foram examinadas e 
as lesões foram confirmadas como sendo metastáticas e de origem prostática por um único patologista da UT-MDACC, com base nas características histopatológicas à microscopia óptica após coloração pela hematoxilina-eosina.

Em relação aos pacientes, a idade média foi de 75,5 anos (variando de 60 a 87 anos). Os dados referentes à idade dos pacientes, ao estadiamento dos tumores e aos regimes terapêuticos foram levantados a partir da revisão dos prontuários. Os pacientes foram estadiados com base no sistema TNM (AMERICAN JOINT COMMITTEE ON CANCER STAGING MANUAL), sendo que todos apresentavam doença metastática, confirmada após a ressecção cirúrgica das lesões suspeitas. Este sistema classifica o estádio com base na extensão local do tumor, no comprometimento dos gânglios linfáticos e na presença de metástases em órgãos à distância.

\subsection{Ensaios de sobreposição de fagos em metástases ósseas de adenocarcinoma de próstata}

Os ensaios de competição para a avaliação da especificidade da ligação dos fagos à proteína GRP78 foram realizados com o anticorpo policlonal IgG anti-GRP78 desenvolvido em cabra C-20 (Santa Cruz Biotechnology, Santa Cruz, CA, EUA) e com o anticorpo controle policlonal IgG desenvolvido em cabra (IgG reagent Grade, Sigma, St. Louis, MO, EUA), com concentrações de imunoglobulinas equivalente. Após a desparafinização 
e rehidratação das lâminas em xileno e gradiente alcoólico, as secções foram tratadas com peróxido de hidrogênio $\left(\mathrm{H}_{2} \mathrm{O}_{2}\right)$ a $2 \%$ em metanol por 20 minutos, visando à inativação da peroxidase endógena. Após bloqueio de eventuais ligações protéicas inespecíficas com o bloqueador protéico do conjunto LSAB+ por 15 minutos, as secções foram incubadas com os fagos 1, 4 e controle negativo (Fd-tet) por duas horas a temperatura ambiente, de forma que o ensaio foi realizado para cada um dos fagos em todos os espécimes de tecido humano obtido. Seguiu-se a adição do anticorpos antiGRP78 e controle diluídos em solução de diluição de anticorpos (LSAB+, $D A K O)$ por uma hora em câmara úmida. As secções foram lavadas com TBST (DAKO, Carpinteria, CA, EUA) e o anticorpo secundário conjugado à peroxidase (DAKO EnVision, Carpinteria, CA, EUA) foi incubado por 30 minutos. A imunohistoquímica e a classificação quanto à imunoreatividade foram realizadas da mesma forma que no item 3.9.

\subsection{Análise estatística}

Para verificar a associação entre as variáveis numéricas, o teste $\mathrm{t}$ de Student foi utilizado, pareando-se as amostras e considerando-se nível de significância de $5 \%$. Todos os resultados foram expressos como médias \pm erro padrão das médias do número de colônias presente nas placas. 


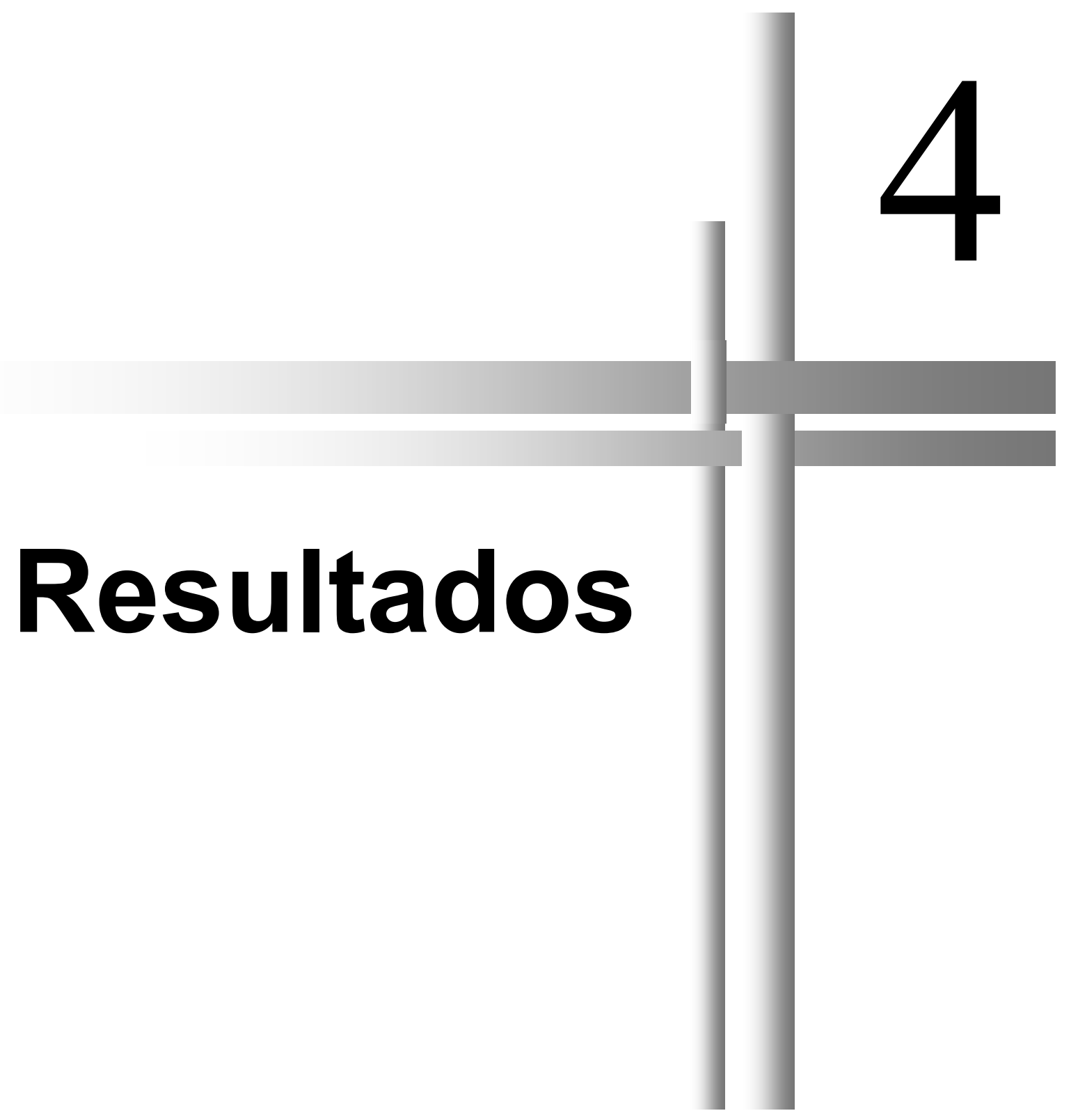




\section{Resultados}

\subsection{Seleção de peptídeos, clonagem e amplificação dos fagos com afinidade à proteína de choque térmico GRP78}

A seleção dos peptídeos com afinidade à proteína de choque térmico GRP78 foi feita com base nos critérios e escores estabelecidos em publicação anterior (BLOND-ELGUINDI et al., 1993). Foram selecionados cinco peptídeos que apresentam forte afinidade à proteína GRP78 (quadro 2) e os plasmídeos (fitas de DNA) correspondentes a estes peptídeos foram clonados no vetor fUSE5. Após a eletroporação dos plasmídeos em Escherichia coli MC1061, os clones produzidos foram amplificados e seqüenciados para a verificação do procedimento de clonagem. A análise das seqüências mostrou que todos os cinco peptídeos foram clonados no vetor fUSE5 com sucesso. Os clones foram então amplificados conforme descrito no item 3.1, titulados e procedeu-se aos ensaios de ligação in vitro. 


\subsection{Ligação específica dos fagos à proteína GRP78 in vitro}

Inicialmente foi determinada a especificidade da ligação dos fagos à proteína GRP78 adsorvida em placas com 96 multipoços (Nalge-Nunc, Naperville, IL). A tabela 2 expõe a contagem de colônias bacterianas representativas da ligação dos fagos 1,4 e controle negativo à proteína GRP78 e às proteínas controle in vitro. O fago 1 (WIFPWIQL) apresentou ligação significativamente maior $(\mathrm{P}=0,006$; teste $\mathrm{t}$ de Student) à proteína GRP78 em comparação com a ligação às proteínas controle: BSA (19,3 vezes), HSP70 (20,8 vezes) e HSP90 (19,3 vezes). Na figura 5 pode-se visualizar nas barras a grande diferença da ligação do fago 1 à proteína GRP78 em relação às outras proteínas testadas.

De forma similar, o fago 4 (WDLAWMFRLPVG) também apresentou ligação in vitro significativamente maior $(P<0,001$; teste $t$ de Student) à proteína GRP78 em comparação com a ligação às proteínas controle: BSA (12 vezes), HSP70 (11,5 vezes) e HSP90 (17,4 vezes). Na figura 6 pode-se verificar a significativa diferença de interação entre o fago 4 e as proteínas estudadas. 


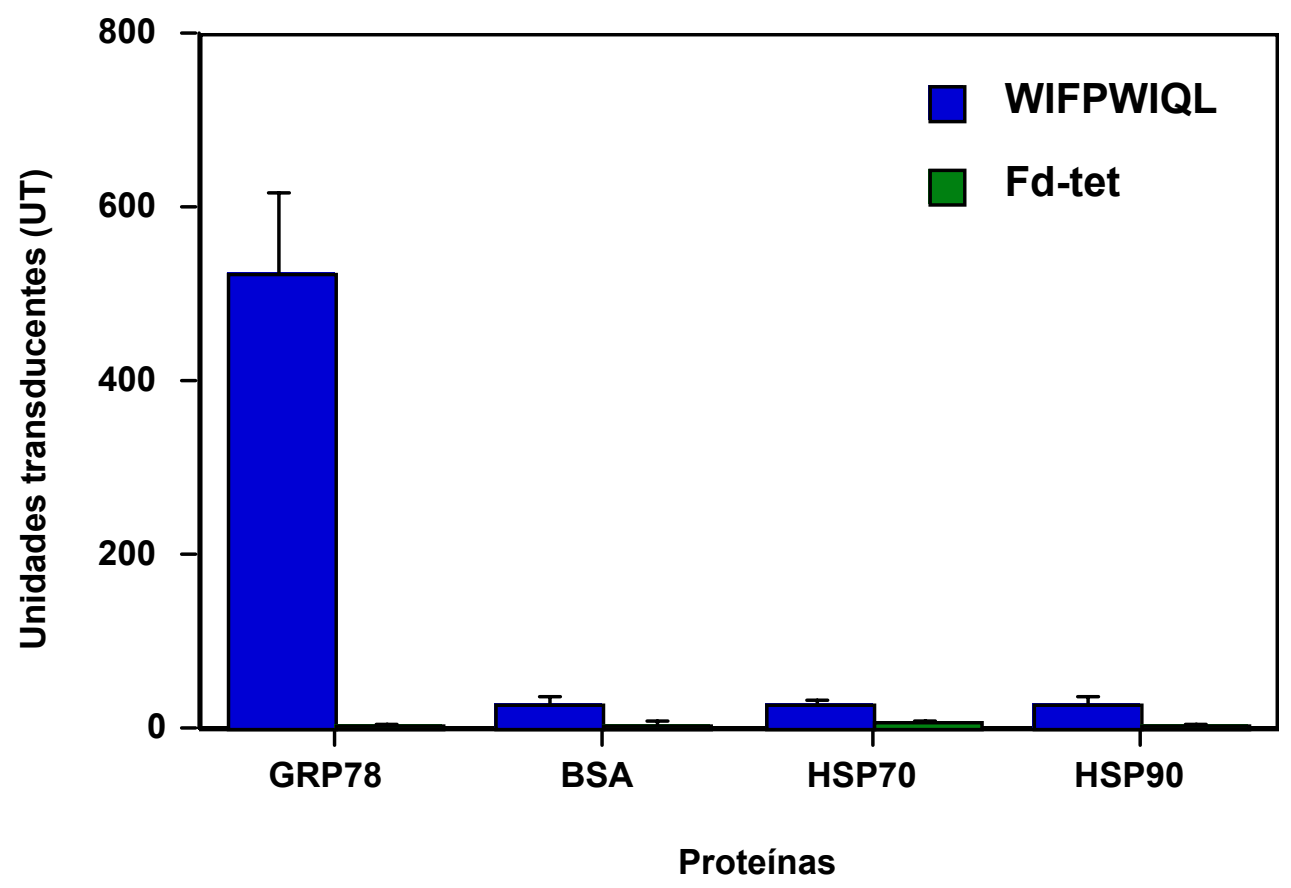

Figura 5. Comparação da ligação in vitro do fago 1 (WIFPWIQL) às proteínas controle (BSA, HSP70 e HSP90). As proteínas foram adsorvidas para o revestimento dos micropoços, todas em solução de $10 \mu \mathrm{g} / \mathrm{ml}$. Os resultados estão expressos como a média dos valores obtidos em três micropoços. Foram utilizadas $10^{9}$ unidades transducentes (U.T.) de cada um dos fagos por micropoço. As barras representam enriquecimento dos fagos \pm erro padrão das médias de triplicatas para a diluição bacteriana mais representativa. 


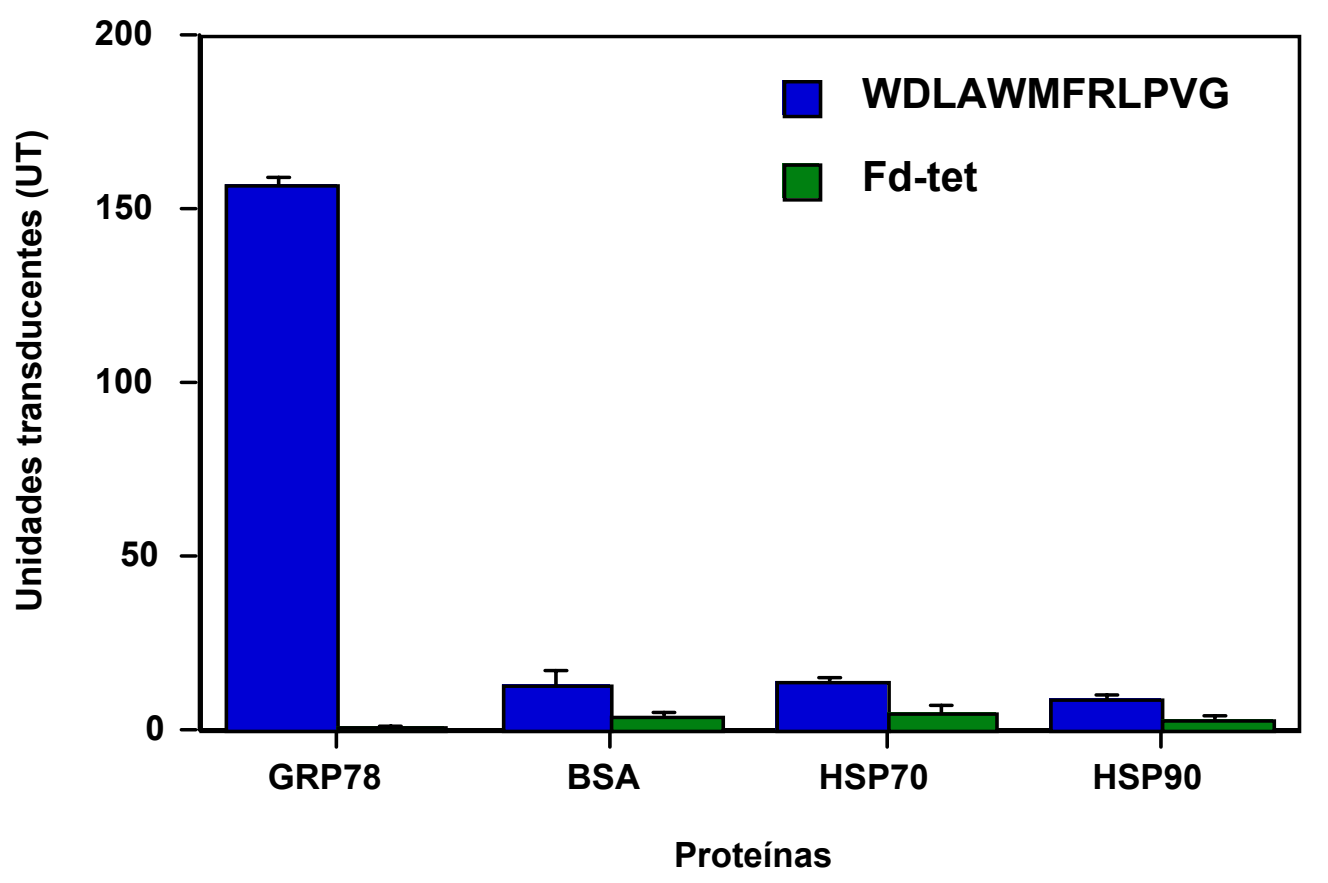

Figura 6. Comparação da ligação in vitro do fago 4 (WDLAWMFRLPVG) às proteínas controle (BSA, HSP70 e HSP90). As proteínas foram adsorvidas para o revestimento de micropoços, todas em solução de $10 \mu \mathrm{g} / \mathrm{ml}$. Os resultados estão expressos como a média dos valores obtidos em três micropoços. Foram utilizadas $10^{9}$ unidades transducentes (U.T.) de cada um dos fagos por micropoço. As barras representam enriquecimento dos fagos \pm erro padrão das médias de triplicatas para a diluição bacteriana mais representativa. 
Tabela 2 - Resultados representativos da ligação dos fagos à proteína GRP78 e às proteínas controle in vitro.

\begin{tabular}{ccccc}
\hline & GRP78 & BSA & HSP70 & HSP90 \\
\hline Fago controle & $0 / 1 / 9$ & $2 / 5 / 4$ & $3 / 5 / 7$ & $4 / 1 / 3$ \\
WIFPWIQL & $629 / 338 / 600$ & $41 / 20 / 20$ & $32 / 20 / 23$ & $12 / 30 / 39$ \\
WDLAWMFRLPVG & $157 / 153 / 160$ & $11 / 9 / 19$ & $13 / 13 / 15$ & $11 / 8 / 8$ \\
\hline \multicolumn{2}{l}{ Os números representam a quantidade de colônias bacterianas recuperadas por placa multiwell na } \\
\multicolumn{4}{l}{ diluição mais representativa $(100 \mu l)$} \\
\hline
\end{tabular}

Nota-se, nas figuras 5 e 6 e na tabela 2 que, além de ligarem-se significativamente mais à proteína GRP78 em comparação às proteínas controle, os fagos 1 e 4 apresentaram ligação significativamente maior (teste t de Student) à proteína GRP78 (870 vezes, $\mathrm{P}=0,005$ e 261 vezes, $\mathrm{P}<0,001$, respectivamente) que o fago controle (Fd-tet). Em contraste, o fago controle não apresentou interação significativa com nenhuma das proteínas estudadas (figuras 1 e 2 e tabela 2). Os fagos 2, 3 e 5 não apresentaram ligação significativamente maior ( $P>0,05$; teste $t$ de Student) à proteína GRP78 em comparação às proteínas controle, portanto não foram mais detalhadamente estudados.

Com o objetivo de testar a especificidade da ligação dos fagos 1 e 4 à proteína GRP78, foram utilizados peptídeos sintéticos correspondentes às seqüências dos fagos para inibir essa ligação. Verifica-se que a ligação de ambos os fagos 1 (figura 7) e 4 (figura 8) à proteína GRP78 é específica, 
uma vez que esta foi inibida de forma dose-dependente pelos peptídeos correspondentes, enquanto o peptídeo controle utilizado (CARAC) não influenciou a interação fago-proteína (figuras 6 e 7). 


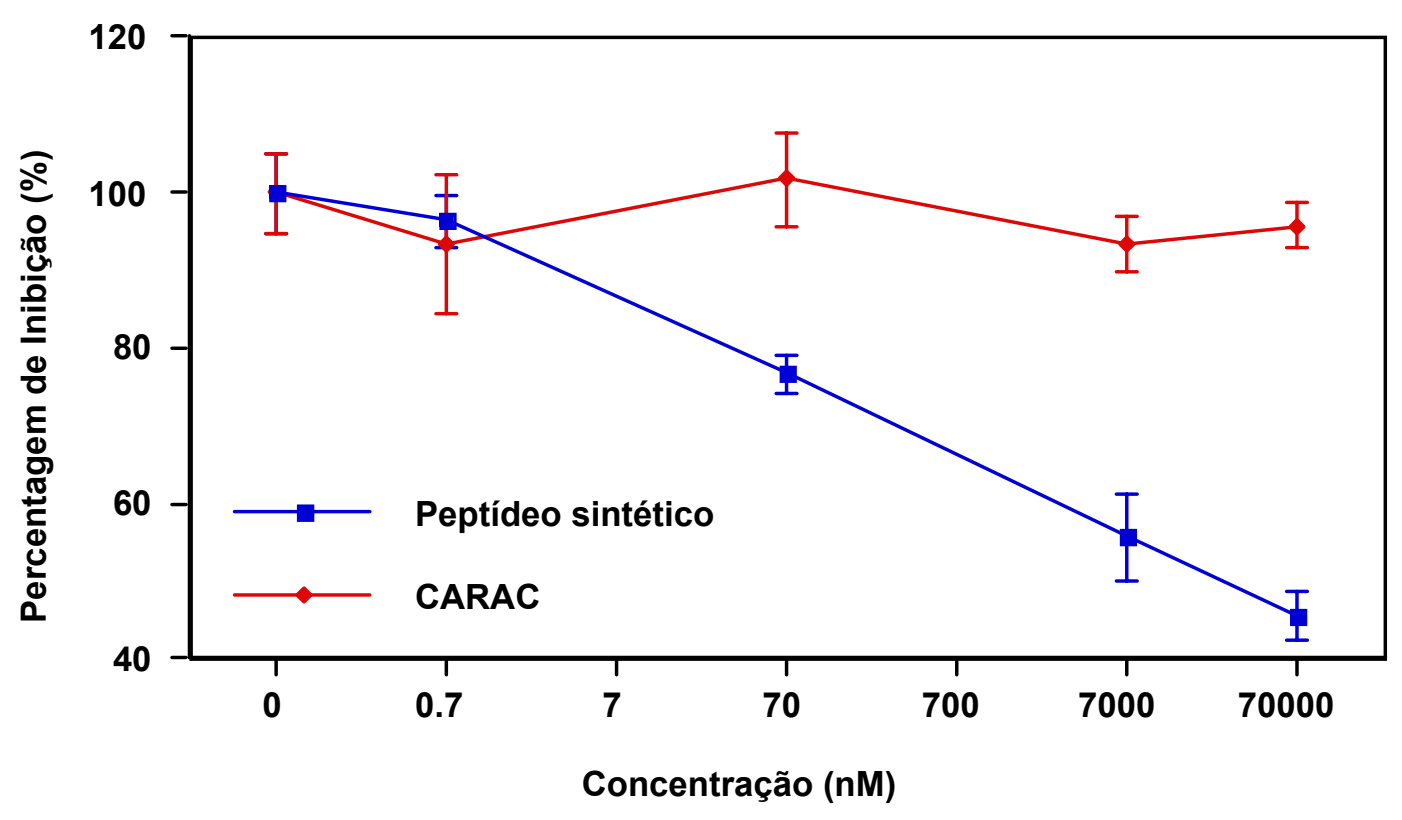

Figura 7. Inibição dose-dependente da ligação do fago 1 (WIFPWIQL) à proteína GRP78. A proteína GRP78 foi adsorvida em placas com 96 micropoços em solução de 10 $\mu \mathrm{g} / \mathrm{ml}$. O fago foi incubado na presença de concentrações progressivamente maiores do peptídeo sintético correspondente e do peptídeo controle (CARAC). Cada ponto na curva de inibição representa a média do número de colônias bacterianas obtida para três placas. A inibição foi realizada três vezes com resultados similares e expressa de acordo com a porcentagem de inibição da ligação do fago em relação à concentração dos peptídeos correspondente e controle. 




Figura 8. Inibição dose-dependente da ligação do fago 4 (WDLAWMFRLPVG) à proteína GRP78. A proteína GRP78 foi adsorvida em placas com 96 micropoços em solução de 10 $\mu \mathrm{g} / \mathrm{ml}$. O fago foi incubado na presença de concentrações progressivamente maiores do peptídeo sintético correspondente e do peptídeo controle (CARAC). Cada ponto na curva de inibição representa a média do número de colônias bacterianas obtida para três placas. A inibição foi realizada três vezes com resultados similares e expressa de acordo com a porcentagem de inibição da ligação do fago em relação à concentração dos peptídeos correspondente e controle. 


\subsection{Ligação específica dos fagos à células de câncer de próstata que expressam a proteína GRP78}

Uma vez determinada a especificidade da ligação dos fagos 1 e 4 à proteína GRP78, foi avaliada a capacidade de ligação dos mesmos fagos à células que expressam a proteína em questão. Inicialmente, a expressão da proteína GRP78 na membrana de células derivadas de câncer de próstata DU145 (MICKEY et al., 1977), previamente avaliada (MINTZ et al., 2003), foi confirmada através do uso da tecnologia de FACS (Fluorescent activated cell sorting). Determinou-se também que uma diluição de 1:50 do anticorpo antiGRP78 em PBS foi suficiente para saturar a proteína GRP78 na membrana celular. Os fagos com afinidade à proteína GRP78 (1 e 4) e o fago controle (Fd-tet) foram incubados com as células malignas derivadas de câncer de próstata DU145. A ligação à estas células foi no mínimo 30 vezes maior (teste $t$ de Student, $\mathrm{P}<0,001$ ) para ambos os fagos com afinidade à proteína GRP78 quando comparada à do fago controle.

Com o objetivo de avaliar a especificidade da interação dos fagos à proteína GRP78 nas células prostáticas em solução, foi utilizado anticorpo policlonal anti-GRP78, proteína GRP78 em solução e os peptídeos cognatos dos fagos para a inibição da ligação. Verifica-se que a interação é específica, uma vez que foi bloqueada significativamente pelo anticorpo, pela proteína e pelo peptídeo cognato tanto para o fago 1 (figura 9), quanto para o fago 4 
(figura 10). Além disso, verifica-se em ambos os ensaios que o fago controle não apresentou ligação significativa com as células prostáticas, independentemente da presença ou ausência dos fatores inibitórios da interação. 



Figura 9. Ligação do fago 1 (WIFPWIQL) à proteína GRP78 expressa em células prostáticas malignas DU145. A inibição da ligação do fago 1 às células prostáticas DU145 foi obtida através da adição de um anticorpo anti-GRP78, da proteína GRP78 em solução e do peptídeo correspondente. As barras representam a percentagem média de ligação dos fagos \pm erro padrão das médias de três experimentos distintos. Os resultados estão expressos de acordo com a porcentagem de inibição da ligação dos fagos, determinada como $100 \%$ para os ensaios realizados sem nenhum fator inibitório 

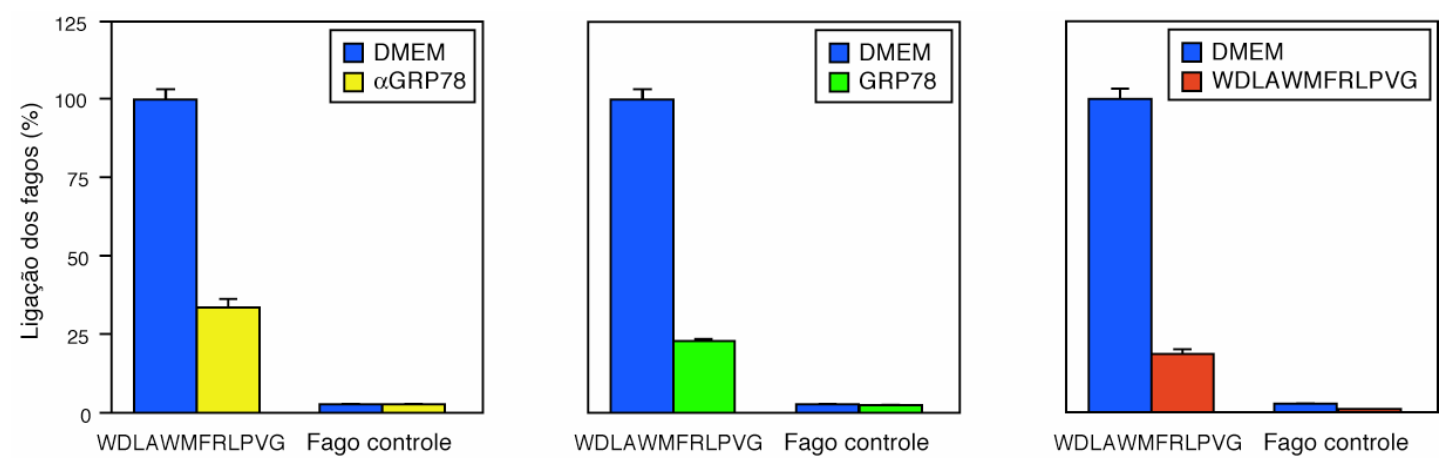

Figura 10. Ligação do fago 4 (WDLAWMFRLPVG) à proteína GRP78 expressa em células prostáticas malignas DU145. A inibição da ligação do fago 4 às células prostáticas DU145 foi obtida através da adição de um anticorpo anti-GRP78, da proteína GRP78 em solução e do peptídeo correspondente. As barras representam a percentagem média de ligação dos fagos \pm erro padrão das médias de três experimentos distintos. Os resultados estão expressos de acordo com a porcentagem de inibição da ligação dos fagos, determinada como $100 \%$ para os ensaios realizados sem nenhum fator inibitório 


\subsection{Internalização dos fagos pelas células prostáticas malignas DU145}

Após demonstração da especificidade da ligação dos fagos à proteína GRP78 em células prostáticas DU145, avaliou-se a capacidade dessas células de internalizarem os fagos. Os fagos 1 e 4 e o fago controle (Fd-tet), em titulação semelhante, foram incubados com células prostáticas DU145 e com células controle (MDA-MB-435, derivadas de câncer de mama) (PRICE et al., 1990). De forma interessante, observa-se que ambos os fagos com afinidade à proteína GRP78 (1 e 4) apresentaram altos níveis de internalização nas células prostáticas, quando comparados ao fago controle. Este, por sua vez, apresentou internalização mínima. Além disso, praticamente não foi observada internalização de nenhum dos fagos nas células controle (figura 11). 


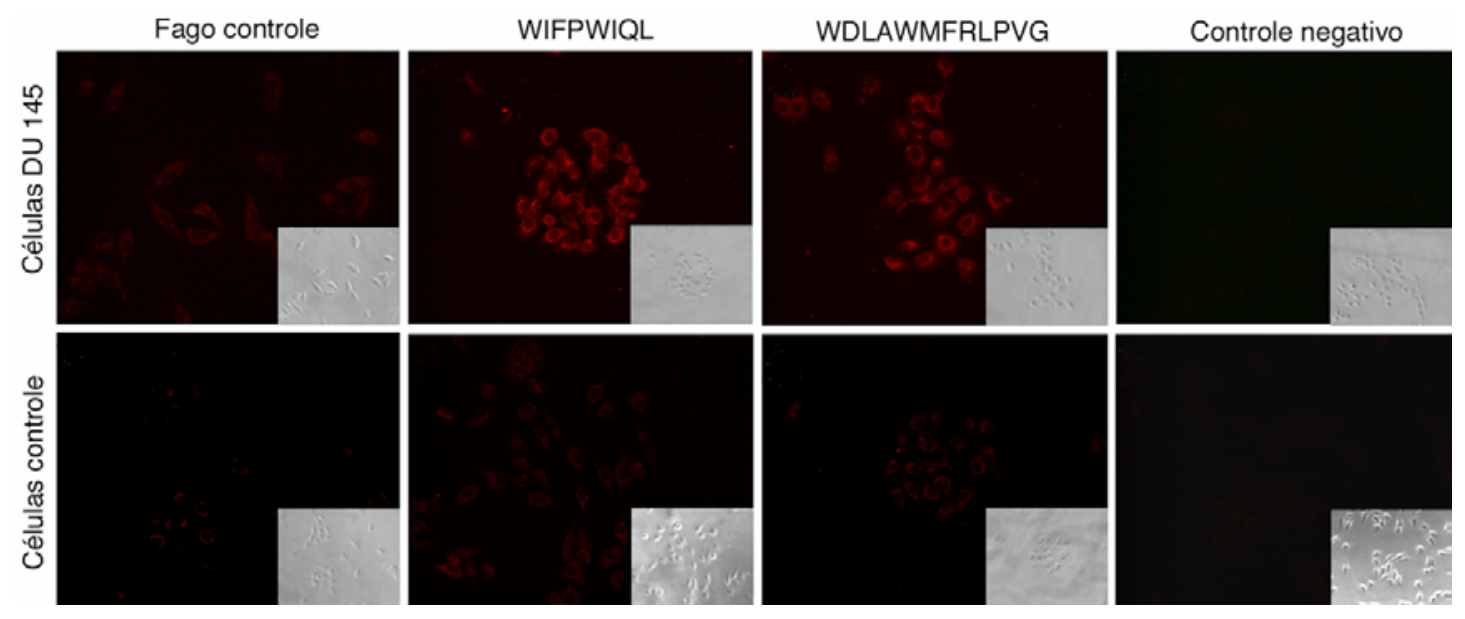

Figura 11. Internalização dos fagos 1 e 4 nas células prostáticas malignas DU145. Os fagos 1,4 e o fago controle negativo foram incubados com as células prostáticas DU145 ou com células controle (derivadas de câncer de mama - MDA-MB-435). Verifica-se nos painéis superiores que os fagos 1 e 4 foram internalizados de forma significativa pelas células prostáticas quando comparados ao fago controle. Nos painéis inferiores, evidencia-se que todos os fagos testados foram muito pouco internalizados pelas células controle. 


\subsection{Ligação dos fagos a tumores prostáticos in vivo}

Após a avaliação da ligação e internalização dos fagos com afinidade à proteína GRP78, o passo seguinte no desenvolvimento do sistema de receptor-ligante em câncer de próstata foi a avaliação da habilidade dos fagos para o rastreamento seletivo a tumores prostáticos in vivo. Para essa avaliação, foram administrados os fagos controle negativo (Fd-tet) e positivo (RGD-4C) (KOIVUNEN et al., 1995) e os fagos 1 e 4 em veia periférica de camundongos tipo atímicos tipo "nude", que estavam desenvolvendo xenoenxertos tumorais prostáticos no tecido celular subcutâneo torácico ventral. Após 24 h de circulação sistêmica dos fagos, os animais foram anestesiados e sacrificados, os tumores e órgãos controle negativo (cérebro) e positivo (fígado) foram ressecados cirurgicamente e analisados para a expressão tecidual dos fagos. A figura 12 representa os achados mais comuns nos ensaios de rastreamento in vivo, realizado em três grupos de animais com três camundongos cada grupo. De forma interessante todos os animais que receberam os fagos 1 e 4 apresentaram forte coloração positiva nos tumores. Além disso, quase não foi detectada coloração para fagos com afinidade à proteína GRP78 nos órgãos controle e o fago controle negativo não foi detectado nem nos tumores nem nos órgãos controle. 




Figura 12. Imunohistoquímica para detecção da ligação dos fagos a tumores prostáticos in vivo. Os fagos foram injetados em veia periférica de camundongos "nude" que apresentavam xenotumores prostáticos implantados no tecido celular subcutâneo ventral. Observamos intensa coloração positiva nos cortes de tumores com ambos os fagos 1 e 4, inclusive com sinal mais intenso que o observado com o fago controle positivo. Não se observa coloração para fagos significativa nos órgãos controle, nem com o fago controle negativo. A barra representa $100 \mu \mathrm{m}$. 


\subsection{Ligação específica dos fagos a metástases ósseas de câncer de próstata}

A análise da ligação dos fagos em espécimes derivadas de metástases ósseas de câncer de próstata foi realizada através da utilização da técnica de sobreposição de fagos. Esta técnica consiste inicialmente na adição de fagos sobre as lâminas de tecido em estudo, seguida de lavagens repetidas. Subseqüentemente, a detecção dos fagos ligados ao tecido é feita através da adição de anticorpo secundário antibacteriófago. Foram utilizados também um anticorpo policlonal anti-GRP78 e um anticorpo controle (ambos do mesmo isotipo e com a mesma concentração de imunoglobulinas) para bloquear a interação e dessa forma avaliar a especificidade da mesma. Verifica-se uma significativa inibição da ligação dos fagos às secções teciduais nas lâminas que receberam o anticorpo anti-GRP78, o que não se repetiu com o anticorpo controle. Esses resultados indicaram que a ligação dos fagos 1 e 4 às amostras de tecido metastático derivado de câncer de próstata é não só forte, mas também específica. A figura 13 expõe os resultados mais representativos dos ensaios de inibição, repetidos em nove espécimes derivados de seis pacientes com adenocarcinoma de próstata metastático. 

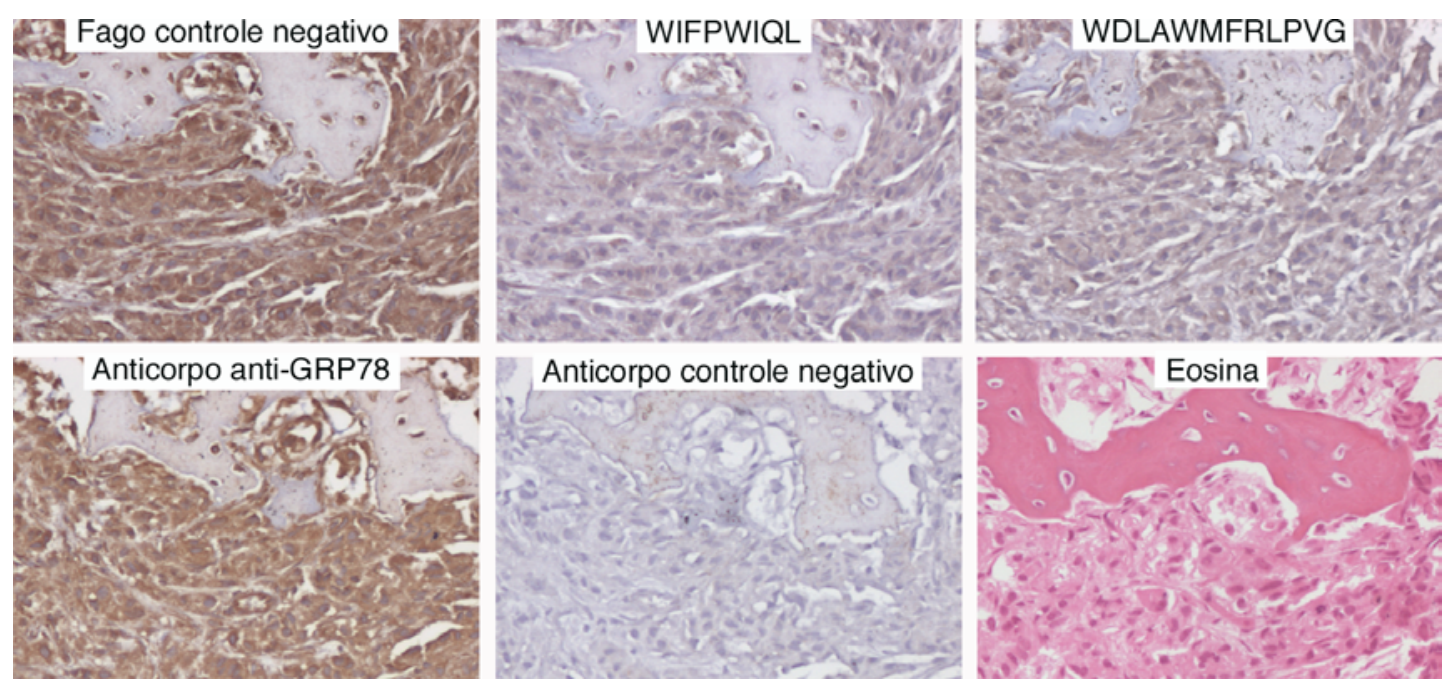

Anticorpo controle negativo

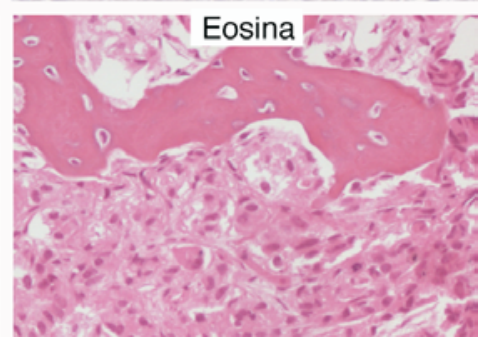

Figura 13. Inibição da ligação dos fagos à metástases ósseas de tumores prostáticos humanos. Os tumores foram incubados com os fagos 1, 4 e controle negativo antes da adição do anticorpo anti-GRP78. Observamos intensa coloração nas seç̧ões quando o anticorpo anti-GRP78 foi utilizado anteriormente à adição dos fagos, enquanto que naquelas que receberam o anticorpo controle, não verificamos coloração positiva. A pré-incubação com ambos os fagos 1 e 4 inibiu significativamente a interação do anticorpo anti-GRP78 aos tumores, enquanto que o fago controle não influenciou essa interação. 


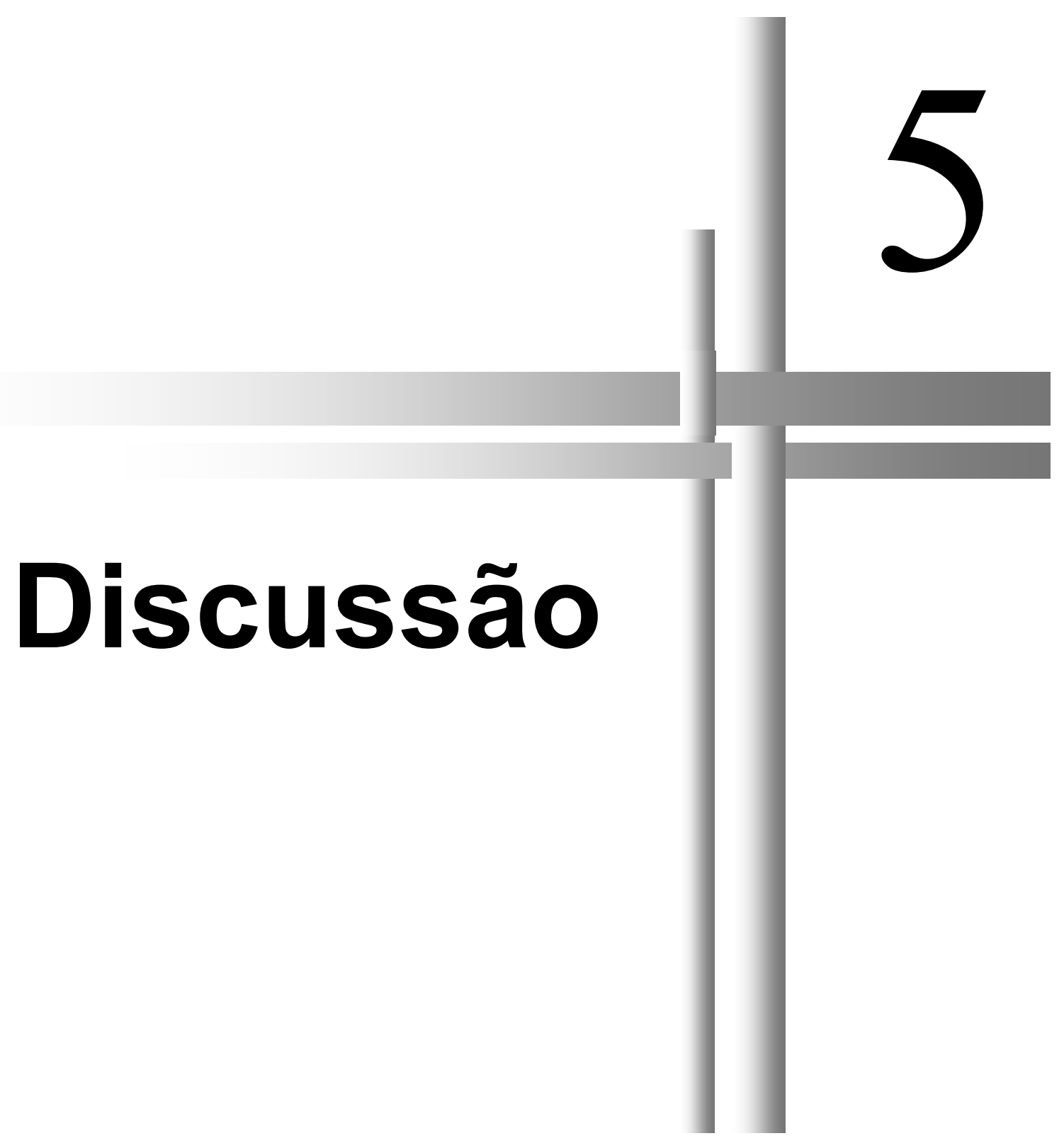




\section{Discussão}

O câncer de próstata é um grande desafio à sociedade e à Medicina. Apresenta elevada prevalência e é responsável por grande número de mortes no Brasil e no mundo (INCA, 2002; AMERICAN CANCER SOCIETY, 2003). O câncer de próstata é notadamente heterogêneo em relação ao seu comportamento. Atualmente não se sabe predizer como será a evolução do tumor uma vez confirmado o diagnóstico. Alguns pacientes vivem com a neoplasia, que permanece estável por décadas sem nenhum tipo de tratamento. Por outro lado, ela pode crescer rapidamente, não responder à terapia e causar a morte dentro de poucos anos, apesar do tratamento agressivo.

Avanços importantes no tratamento do câncer de próstata foram alcançados com a padronização das técnicas cirúrgicas e dos diversos tratamentos adjuvantes. Entretanto, quando existe invasão extra-prostática, as taxas de cura são reduzidas e em grande parte dos pacientes 0 desenvolvimento de doença androgênio-independente é um fenômeno inevitável. O grande desafio no tratamento do câncer de próstata é a ablação do tumor primário antes do desenvolvimento de metástases, uma vez que apesar das diversas modalidades de tratamento não existe terapia curativa para pacientes com doença metastática. Novas estratégias como as terapias 
dirigidas são então necessárias, tanto para o tratamento do tumor primário quanto para o tratamento das metástases à distância.

A criação de sistemas de receptores/ligantes é um passo estratégico para o desenvolvimento de terapias dirigidas. Várias linhas de pesquisa recentes têm sugerido que as proteínas de choque térmico presentes na membrana de células tumorais podem servir como alvo molecular. Primeiro, o estudo do perfil protéico expresso na membrana de células tumorais de várias origens revelou grande número de proteínas chaperonas de choque térmico, inclusive da proteína GRP78 (SHIN et al., 2003). Segundo, a identificação do repertório circulante de anticorpos em pacientes com câncer de próstata através do uso da tecnologia de apresentação de fagos revelou um peptídeo que mimetiza conformacionalmente a GRP78 (MINTZ et al., 2003). Finalmente, A GRP78 expressa na membrana de células de adenocarcinoma de próstata aparentemente tem papel na transdução do sinal da $\propto 2$-macroglobulina (MISRA et al., 2002), uma molécula inibidora de protease plasmática que se liga também ao PSA (KANOH et al., 2001). De forma interessante, MINTZ e colaboradores mostraram que a resposta imune contra à GRP78 mostrou correlação com doença hormônio-independente e com redução de sobrevida numa população grande de pacientes com câncer de próstata (MINTZ et al., 2003). Essas observações nos incentivaram a avaliar a possibilidade de utilizar a expressão da GRP78 na membrana de células tumorais como alvo 
para o desenvolvimento de um sistema de receptor/ligante no câncer de próstata.

No presente estudo foram desenhados e validados sistemas baseados na proteína GRP78 para o rastreamento in vivo do câncer de próstata. Para sua função de chaperona, a GRP78 depende da habilidade em reconhecer e se ligar a polipeptídeos com diversas seqüências e ao mesmo tempo deve reconhecer proteínas com estrutura tridimensional incorreta (BLOND-ELGUINDI, 1993). Apesar disso, foi demonstrado que a GRP78 tem afinidade preferencial a peptídeos ricos em triptofano, fenilalanina e leucina e posições alternadas. Inicialmente foram gerados fagos com capacidade de ligação à GRP78 através da seleção e clonagem dos peptídeos WIFPWIQL e WDLAWMFRLPVG no vetor fUSE5. De forma interessante, os dois fagos criados apresentaram afinidade significativamente maior à GRP78 em relação às proteínas controle relacionadas e não relacionadas nos ensaios in vitro. Além disso, os peptídeos cognatos inibiram a ligação de forma dosedependente, comprovando a especificidade da interação. Os resultados obtidos in vitro sugerem que os peptídeos expostos nos fagos ligam-se a sítios provavelmente específicos da GRP78, não compartilhados pelas outras proteínas de choque térmico testadas aqui, como a HSP-70 e a HSP-90.

O passo seguinte no desenvolvimento do sistema de receptor/ligante foi availar a capacidade de ligação dos fagos à GRP78 expressa na membrana de células tumorais prostáticas intactas. Para tanto 
foi utilizado o teste BRASIL (GIORDANO et al., 2001), baseado em centrifugação diferencial na qual a suspensão celular, incubada com fagos em uma fase superior aquosa, é centrifugada através de uma fase inferior orgânica não miscível. Essa separação de fase orgânica em etapa única é mais rápida, mais sensível e mais específica do que os métodos habituais baseados em etapas de lavagem ou na limitação da diluição (GIORDANO et al., 2001). Após a centrifugação da suspensão de células DU145, foi mostrado que os fagos com afinidade à GRP78 in vitro também rastrearam a GRP78 expressa na membrana das células em questão. Além disso, essa interação foi novamente específica, uma vez que a ligação foi inibida pela proteína em solução, por anticorpo anti-GRP78 e pelos peptídeos cognatos ao fago. O sucesso dos ensaios em células vivas sugere que, apesar da GRP78 estar em posição trans-membrânica (MINTZ et al., 2003), os peptídeos expostos nos fagos ligam-se a sítios na proteína provavelmente expostos em sua porção extra-celular.

A internalização de quimioterápicos, drogas pró-apoptóticas e outros agentes utilizados no tratamento de tumores é um fenômeno necessário para o sucesso da ablação de órgãos e tecidos em terapia dirigida (ARAP et al., 2002a; ARAP et al., 1998; ELLERBY et al., 1999; KOIVUNEN et al., 1999a). Para avaliar a possibilidade de internalização dos fagos nas células tumorais, foi realizado ensaio de comparação entre os fagos que expressam os peptídeos WIFPWIQL e WDLAWMFRLPVG e o fago controle 
negativo (fd-tet). Ambos os fagos com afinidade à GRP78 foram internalizados de forma eficiente pelas células tumorais prostáticas, o que não se repetiu com o fago contole. A capacidade das células em internalizar os fagos pode estar relacionada a algumas das funções da GRP78, como o transporte de proteínas do retículo endoplasmático (LEE, 2001) e apresentação de antígenos (MELNICK; ARGON, 1995).

Um dos grandes obstáculos antes da aplicação clínica de terapias dirigidas é a falta de métodos eficazes para o rastreamento in vivo dos ligantes, principalmente devido à toxicidade dos vetores (EBARA et al., 2002) e aos mecanismos fisiológicos de degradação dos compostos administrados. A utilização in vivo da tecnologia de apresentação de fagos foi inicialmente aplicada para o estudo de peptídeos que rastreiam seletivamente a vasculatura de órgãos de interesse (PASQUALINI; RUOSLAHTI，1996). Em publicação recente foi utilizada tecnologia de apresentação de fagos em seres humanos (ARAP et al., 2002b). Apesar de dificuldades técnicas iniciais, o sistema apresenta grandes vantagens que determinam seu sucesso. Inicialmente, ele permite avaliar o rastreamento de órgãos e tecidos de uma maneira funcional. Segundo, os peptídeos utilizados in vivo devem sobrepujar mecanismos fisiológicos de degradação, semelhantes em animais e em humanos, tais como a degradação celular e a excreção renal e hepática. Terceiro, a utilização dos fagos in vivo inclui um passo de bloqueio inerente ao método, no qual peptídeos que reconhecem proteínas 
plasmáticas e da membrana de eritrócitos são depletados do pool circulante. Finalmente, essa tecnologia mostrou-se capaz de identificar e validar peptídeos que ligam-se especificamente a diferentes órgãos e, o que é ainda mais importante, a receptores seletivamente expressos em sub-populações celulares dentro de um órgão ou tecido de interesse (KOLONIN et al., 2001). Com o objetivo de avaliar a capacidade dos fagos de rastrear xeno-tumores derivados de células prostáticas humanas in vivo, foram administrados os fagos em estudo e os fagos controle em camundongos atímicos.

Os resultados dos ensaios in vivo mostram que os peptídeos com afinidade à GRP78 promovem o rastreamento de tumores prostáticos humanos enxertados em animais de experimentação. Após longo período de circulação dos fagos (24h), observamos intensa localização dos mesmos nos tumores, com sinal quase inexistente nos órgãos controle. Considerando a capacidade das células DU145 em internalizar os fagos (figura 11), o tempo prolongado de circulação sistêmica dos mesmos e o padrão de coloração observado in vivo (figura 12), é provável que a GRP78 seja o receptor que determina internalização dos fagos ocorrida nas células tumorais.

Células prostáticas malignas sofrem modificações genéticas, funcionais e fenotípicas antes de adquirir potencial metastático (DONALD et al., 2001; MALINS et al., 2003). Essas alterações incluem mudanças na capacidade de adesão, motilidade e potencial de invasão (DONALD et al., 2001). Com essas modificações, os receptores existentes em células do 
tumor primário podem sofrer regulação positiva ou negativa e portanto ligantes que previamente apresentavam intensa afinidade por receptores na superfície celular podem não mais reconhecê-los. Com essa perspectiva, após a avaliação da capacidade de rastreamento dos tumores in vivo, foi verificada a capacidade de ligação dos fagos a metástases ósseas. Curiosamente, os fagos mostraram forte capacidade de ligação às metástases, inclusive mais intensa que a observada para o fago controle positivo. Os resultados obtidos com as metástases provavelmente refletem a expressão aumentada de GRP78 em tumores metastáticos hormônioindependentes (MINTZ et al., 2003).

A especificidade da interação dos fagos com as metástases foi verificada através de um ensaio de competição com um anticorpo antiGRP78. Os fagos mostraram inibir a coloração para os anticorpos, presumivelmente devido ao tamanho de suas partículas, que podem romper a interação antígeno-anticorpo. Os resultados de coloração e os ensaios de inibição sugerem especificidade para a ligação dos peptídeos com afinidade à GRP78 e às metástases.

Coletivamente, os dados apresentados nesse trabalho mostram que a GRP78 expressa na superfície de células tumorais prostáticas formam as bases para o desenvolvimento de um sistema de receptor/ligante para o rastreamento do câncer de próstata. Além disso, os peptídeos aqui utilizados, quando associados a quimioterápicos e/ou drogas pró-apoptóticas (ELLERBY 
et al. 1999) podem permitir o desenvolvimento de futuras terapias dirigidas contra a doença. 







\section{Conclusões}

1. Foi possível a clonagem no vetor fUSE5 do DNA correspondente a peptídeos que apresentam afinidade específica à proteína GRP78.

2. Os fagos clonados apresentam afinidade específica pela GRP78 in vitro.

3. Os fagos clonados apresentam ligação específica a GRP78 expressa em células prostáticas malignas DU145.

4. Os fagos com afinidade à GRP78 são internalizados pelas células DU145 e não por células controle.

5. Os fagos apresentam capacidade de rastrear xeno-tumores prostáticos quando injetados in vivo.

6. Os fagos clonados têm a capacidade de ligação a metástases ósseas de adenocarcinoma de próstata humano. 
Referências Bibliográficas 


\section{Referências Bibliográficas}

ADAMI, H. O., BERGSTROM, R., ENGHOLM, G., NYREN, O., WOLK, A., EKBOM, A., ENGLUND, A., and BARON, J. (1996). A prospective study of smoking and risk of prostate cancer. Int. J. Cancer 67, 764-768.

AMERICAN JOINT COMMITTEE ON CANCER STAGING MANUAL (1997). Prostate. In AJCC staging manual, I. D. Flemming, J. S. Cooper, and D. E. Hemson, eds. (Philadelphia, JP Lippincott), pp. 219-222.

AMERICAN CANCER SOCIETY. In: Cancer facts and figures, p. 4. 2003.(http://www.cancer.org/downloads/STT/CancerFacts\&Figures2002T M.pdf). Acessado em 8 de Agosto de 2003.

ARAP, W., HAEDICKE, W., BERNASCONI, M., KAIN, R., RAJOTTE, D., KRAJEWSKI, S., ELLERBY, H. M., BREDESEN, D. E., PASQUALINI, R., and RUOSLAHTI, E. (2002a). Targeting the prostate for destruction through a vascular address. Proc. Natl. Acad. Sci. U. S. A. 99, 1527-1531.

ARAP, W., KOLONIN, M. G., TREPEL, M., LAHDENRANTA, J., CARDO-VILA, M., GIORDANO, R. J., MINTZ, P. J., ARDELT, P. U., YAO, V. J., VIDAL, C. I., CHEN, L., FLAMM, A., VALTANEN, H., WEAVIND, L.M., HICKS, M.E., POLLOCK, R.E., BOTZ, G.H., BUCANA, C.D., KOIVUNEN, E., CAHILL, D., TRONCOSO, P., BAGGERLY, K.A., PENTZ, R. D., DO, K. A., LOGOTHETHIS 
C. J. PASQUALINI, R. (2002b). Steps toward mapping the human vasculature by phage display. Nat. Med .8, 121-127.

ARAP, W., PASQUALINI, R., and RUOSLAHTI, E. (1998). Cancer treatment by targeted drug delivery to tumor vasculature in a mouse model. Science $279,377-380$.

ARDELT, P. U., WOOD, C. G., CHEN, L., MINTZ, P. J., MOYA, C., ARAP, M. A., WRIGHT, K. C., PASQUALINI, R., and ARAP, W. (2003). Targeting urothelium: ex vivo assay standardization and selection of internalizing ligands. J. Urol. 169, 1535-1540.

BABAIAN, R. J., ZAGARS, G. K., and AYALA, A. G. (1990). Radiation therapy of stage C prostate cancer: significance of Gleason grade to survival. Semin. Urol. 8, 225-231.

BARRETT-CONNOR, E., GARLAND, C., MCPHILLIPS, J. B., KHAW, K. T., and WINGARD, D. L. (1990). A prospective, population-based study of androstenedione, estrogens, and prostatic cancer. Cancer. Res. 50, 169173.

BLOND-ELGUINDI, S., CWIRLA, S. E., DOWER, W. J., LIPSHUTZ, R. J., SPRANG, S. R., SAMBROOK, J. F., and GETHING, M. J. (1993). Affinity panning of a library of peptides displayed on bacteriophages reveals the binding specificity of BiP. Cell 75, 717-728. 
BRASSO, K., and IVERSON, P. (1999). Prostate cancer in Denmark. Incidence, morbidity and mortality. Scand. J. Urol. Nephrol. Suppl 203, 29-33.

CARTER, B. S., BEATY, T. H., STEINBERG, G. D., CHILDS, B., and WALSH, P. C. (1992). Mendelian inheritance of familial prostate cancer. Proc. Natl. Acad. Sci. U. S. A. 89, 3367-3371.

CARTER, H. B., and PARTIN, A. W. (2002). Diagnosis and staging of prostate cancer. In Campbell's Urology, P. C. Walsh, ed. (Philadelphia, Saunders), pp. 3055-3079.

CLINTON, S. K., PALMER, S. S., SPRIGGS, C. E., and VISEK, W. J. (1988). Growth of Dunning transplantable prostate adenocarcinomas in rats fed diets with various fat contents. J. Nutr. 118, 908-914.

COLTMAN, C. A. Jr, THOMPSON, I. M. Jr, FEIGK, P. (1999). Prostate Cancer Prevention Trial (PCPT) update. Eur. Urol. 35, 544-547.

DANIELL, H. W. (1997). Osteoporosis after orchiectomy for prostate cancer.

J. Urol. $157,439-444$.

DATTOLI, M., WALLNER, K., TRUE, L., CASH, J., and SORACE, R. (2003). Long-term outcomes after treatment with external beam radiation therapy and palladium 103 for patients with higher risk prostate carcinoma: influence of prostatic acid phosphatase. Cancer 97, 979-983.

DEL REgATO, J. A., TRAILINS, A. H., and PITTMAN, D. D. (1993). Twenty years follow-up of patients with inoperable cancer of the prostate (stage 
C) treated by radiotherapy: report of a national cooperative study. Int. J. Radiat. Oncol. Biol. Phys. 26, 197-201.

DELPINO, A., and CASTELLI, M. (2002). The $78 \mathrm{kDa}$ glucose-regulated protein (GRP78/BIP) is expressed on the cell membrane, is released into cell culture medium and is also present in human peripheral circulation. Biosci. Rep. 22, 407-420.

DONALD, C. D., COOPER, C. R., HARRIS-HOOKER, S., EMMETT, N., SCANLON, M., and COOKE, D. B., 3rd (2001). Cytoskeletal organization and cell motility correlates with metastatic potential and state of differentiation in prostate cancer. Cell Mol. Biol. (Noisy-le-grand) 47, 1033-1038.

EBARA, S., SHIMURA, S., NASU, Y., KAKU, H., KUMON, H., YANG, G., WANG, J., TIMME, T. L., AGUILAR-CORDOVA, E., and THOMPSON, T. C. (2002). Gene therapy for prostate cancer: toxicological profile of four HSV-tk transducing adenoviral vectors regulated by different promoters. Prostate Cancer Prostatic Dis. 5, 316-325.

ELLERBY, H. M., ARAP, W., ELLERBY, L. M., KAIN, R., ANDRUSIAK, R., Rio, G. D., KRAJEWSKI, S., LOMBARDO, C. R., RAO, R., RUOSLAHTI, E., BREDESEN, D. E. AND PASQUALINI, R. (1999). Anti-cancer activity of targeted pro-apoptotic peptides. Nat. Med. 5, 1032-1038.

EPSTEIN, J. I. (2002). Pathology of prostatic neoplasia. In Campbell's Urology, P. C. Walsh, ed. (Philadelphia, Saunders), pp. 3025-3037. 
EWINGS, P., and BOWIE, C. (1996). A case-control study of cancer of the prostate in Somerset and east Devon. Br. J. Cancer 74, 661-666.

FERNANDEZ, P. M., TABBARA, S. O., JACOBS, L. K., MANNING, F. C., TSANGARIS, T. N., SCHWARTZ, A. M., KENNEDY, K. A., and PATIERNO, S. R. (2000). Overexpression of the glucose-regulated stress gene GRP78 in malignant but not benign human breast lesions. Breast Cancer Res. Treat. 59, 15-26.

FOWLER, F. J., Jr., MCNAUGHTON COLLINS, M., WALKER CORKERY, E., ELLIOTT, D. B., and BARRY, M. J. (2002). The impact of androgen deprivation on quality of life after radical prostatectomy for prostate carcinoma. Cancer 95, 287-295.

GANN, P. H., HENNEKENS, C. H., MA, J., LONGCOPE, C., and STAMPFER, M. J. (1996). Prospective study of sex hormone levels and risk of prostate cancer. J. Natl. Cancer Inst . 88, 1118-1126.

GIORDANO, R. J., CARDO-VILA, M., LAHDENRANTA, J., PASQUALINI, R., and ARAP, W. (2001). Biopanning and rapid analysis of selective interactive ligands. Nat. Med. 7, 1249-1253.

GIOVANNUCCI, E., RIMM, E. B., COLDITZ, G. A., STAMPFER, M. J., ASCHERIO, A., CHUTE, C. C., and WILLETT, W. C. (1993). A prospective study of dietary fat and risk of prostate cancer. J. Natl. Cancer Inst. 85, 1571-1579. 
GLEASON, D. F., and MELLINGER, G. T. (1974). Prediction of prognosis for prostatic adenocarcinoma by combined histological grading and clinical staging. J. Urol. 111, 58-64.

GLOVER, F. E., Jr., COFFEY, D. S., DOUGLAS, L. L., CADOGAN, M., RUSSELL, H., TULLOCH, T., BAKER, T. D., WAN, R. L., and WALSH, P. C. (1998). The epidemiology of prostate cancer in Jamaica. J. Urol. 159, 19841986; discussion 1986-1987.

GUESS, H. A., FRIEDMAN, G. D., SADLER, M. C., STANCZYK, F. Z., VOGELMAN, J. H., IMPERATO-MCGINLEY, J., LOBO, R. A., and ORENTREICH, N. (1997). 5 alpha-reductase activity and prostate cancer: a case-control study using stored sera. Cancer Epidemiol. Biomarkers Prev. 6, 21-24.

HAAS, I. G., and WABL, M. (1983). Immunoglobulin heavy chain binding protein. Nature 306, 387-389.

HAN, M., and PARTIN, A. W. (2002). Nomograms for clinically localized prostate cancer. Part I: radical prostatectomy. Semin. Urol. Oncol. 20, 123-130.

HUANG, G. M. (1999). High-throughput DNA sequencing: a genomic data manufactoring process. DNA Seq. 10, 149-153.

INCA. In: Atlas de mortalidade por Câncer no Brasil 1979-1999. Rio de Janeiro, 2002. (http://www.inca.org.br/atlas). Acessado em 20 de Agosto de 2003. 
JAMORA, C., DENNERT, G., and LEE, A. S. (1996). Inhibition of tumor progression by suppression of stress protein GRP78/BiP induction in fibrosarcoma B/C10ME. Proc. Natl. Acad. Sci. U. S. A. 93, 7690-7694.

JANI, A. B., and HELLMAN, S. (2003). Early prostate cancer: clinical decisionmaking. Lancet 361, 1045-1053.

JOLLY, C., MORIMOTO, R. I. (2000). Role of the heat shock response and molecular chaperones in oncogenes and cell death. J. Natl. Cancer Inst. $92,1564-1572$.

KANOH, Y., OHTANI, N., MASHIKO, T., OHTANI, S., NISHIKAWA, T., EGAWA, S., BABA, S., and OHTANI, H. (2001). Levels of alpha 2 macroglobulin can predict bone metastases in prostate cancer. Anticancer Res. 21, 551-556.

KATAYAMA, T., IMAIZUMI, K., SATO, N., MIYOSHI, K., KUDO, T., HITOMI, J., MORIHARA, T., YONEDA, T., GOMI, F., MORI, Y., NAKANO, Y., TAKEDA, J., TSUDA, T., ITOYAMA, Y., MURAYAMA, O., TAKASHIMA, A., ST GEORGE-HYSLOP, P., TAKEDA, M., and TOHYAMA, M. (1999). Presenilin-1 mutations downregulate the signalling pathway of the unfolded-protein response. Nat. Cell Biol. 1, 479-485.

KOIVUNEN, E., ARAP, W., RAJOTTE, D., LAHDENRANTA, J., and PASQUALINI, R. (1999a). Identification of receptor ligands with phage display peptide libraries. J. Nucl. Med. 40, 883-888. 
KOIVUNEN, E., ARAP, W., VAltanen, H., RAINiSAlo, A., MedinA, O. P., HEIKKILA, P., KANTOR, C., GAHMBERG, C. G., SALO, T., KONTTINEN, Y. T., SORSA, T., RUOSLAHTI, E. and PASQUALINI, R. (1999b). Tumor targeting with a selective gelatinase inhibitor. Nat. Biotechnol. 17, 768774.

KOIVUNEN, E., RESTEL, B. H., RAJOTTE, D., LAHDENRANTA, J., HAGEDORN, M., ARAP, W., and PASQUALINI, R. (1999c). Integrin-binding peptides derived from phage display libraries. Methods Mol. Biol. 129, 3-17.

KOIVUNEN, E., WANG, B., and RUOSLAHTI, E. (1995). Phage libraries displaying cyclic peptides with different ring sizes: ligand specificities of the RGD-directed integrins. Biotechnology (N Y) 13, 265-270.

KOLONIN, M., PASQUALINI, R., and ARAP, W. (2001). Molecular addresses in blood vessels as targets for therapy. Curr. Opin. Chem. Biol. 5, 308313.

KOLONIN, M. G., PASQUALINI, R., and ARAP, W. (2002). Teratogenicity induced by targeting a placental immunoglobulin transporter. Proc. Natl. Acad. Sci. U. S. A. 99, 13055-13060.

LEE, A. S. (1992). Mammalian stress response: induction of the glucoseregulated protein family. Curr. Opin. Cell. Biol. 4, 267-273.

LEE, A. S. (2001). The glucose-regulated proteins: stress induction and clinical applications. Trends Biochem. Sci. 26, 504-510. 
LEPOR, H. (2003). Practical considerations in radical retropubic prostatectomy. Urol. Clin. North Am. 30, 363-368.

LEWIN, B. (2000). Protein localization. In Genes VII, B. Lewin, ed. (Oxford, Oxford University Press), pp. 191-230.

LIM, A. J., BRANDON, A. H., FIEDLER, J., BRICKMAN, A. L., BOYER, C. I., RAUB, W. A., Jr., and SOLOWAY, M. S. (1995). Quality of life: radical prostatectomy versus radiation therapy for prostate cancer. J. Urol. 154, $1420-1425$.

LITTLE, E., RAMAKRISHNAN, M., ROY, B., GAZIT, G., and LEE, A. S. (1994). The glucose-regulated proteins (GRP78 and GRP94): functions, gene regulation, and applications. Crit. Rev. Eukaryot. Gene Expr. 4, 1-18.

LITTLE, E., TOCCO, G., BAUDRY, M., LEE, A. S., and SCHREIBER, S. S. (1996). Induction of glucose-regulated protein (glucose-regulated protein 78/BiP and glucose-regulated protein 94 ) and heat shock protein 70 transcripts in the immature rat brain following status epilepticus. Neuroscience 75, 209-219.

LIU, H., BOWES, R. C., 3rd, VAN DE WATER, B., SILLENCE, C., NAGELKERKE, J. F., and STEVENS, J. L. (1997). Endoplasmic reticulum chaperones GRP78 and calreticulin prevent oxidative stress, Ca2+ disturbances, and cell death in renal epithelial cells. J. Biol. Chem. 272, 21751-21759. 
MALINS, D. C., JOHNSON, P. M., BARKER, E. A., POLISSAR, N. L., WHEELER, T. M., and ANDERSON, K. M. (2003). Cancer-related changes in prostate DNA as men age and early identification of metastasis in primary prostate tumors. Proc. Natl. Acad. Sci. U. S. A. 100, 5401-5406.

MARVIN, D. A. (1998). Filamentous phage structure, infection and assembly. Curr. Opin. Struct. Biol. 8, 150-158.

MARVIN, D. A., HALE, R. D., NAVE, C., and HELMER-CITTERICH, M. (1994). Molecular models and structural comparisons of native and mutant class I filamentous bacteriophages Ff (fd, f1, M13), If1 and IKe. J. Mol. Biol. $235,260-286$.

MELNICK, J., and ARGON, Y. (1995). Molecular chaperones and the biosynthesis of antigen receptors. Immunol. Today 16, 243-250.

MICKEY, D. D., STONE, K. R., WUNDERLI, H., MICKEY, G. H., VOLLMER, R. T., and PAULSON, D. F. (1977). Heterotransplantation of a human prostatic adenocarcinoma cell line in nude mice. Cancer Res. 37, 40494058.

MINTZ, P. J., KIM, J., DO, K. A., WANG, X., ZINNER, R. G., CRISTOFANILLI, M., ARAP, M. A., HONG, W. K., TRONCOSO, P., LOGOTHETIS, C. J., PASQUALINI, R. and ARAP, W. (2003). Fingerprinting the circulating repertoire of antibodies from cancer patients. Nat. Biotechnol. 21, 5763. 
MISRA, U. K., GONZALEZ-GRONOW, M., GAWDI, G., HART, J. P., JOHNSON, C. E., and PIZZO, S. V. (2002). The role of Grp 78 in alpha 2macroglobulin-induced signal transduction. Evidence from RNA interference that the low density lipoprotein receptor-related protein is associated with, but not necessary for, GRP 78-mediated signal transduction. J. Biol. Chem. 277, 42082-42087.

MIYAKE, H., HARA, I., ARAKAWA, S., and KAMIDONO, S. (2000). Stress protein GRP78 prevents apoptosis induced by calcium ionophore, ionomycin, but not by glycosylation inhibitor, tunicamycin, in human prostate cancer cells. J. Cell Biochem. 77, 396-408.

MORIMOTO, R. I. (1993). Cells in stress: transcriptional activation of heat shock genes. Science 259, 1409-1410.

MUIR, C. S., NECTOUX, J., and STASZEWSKI, J. (1991). The epidemiology of prostatic cancer. Geographical distribution and time-trends. Acta Oncol. $30,133-140$.

MUNRO, S., and PELHAM, H. R. (1986). An Hsp70-like protein in the ER: identity with the $78 \mathrm{kd}$ glucose-regulated protein and immunoglobulin heavy chain binding protein. Cell 46, 291-300.

PASQUALINI, R., and ARAP, W. (2002). Vascular targeting. In Encyclopedia of Cancer, J. R. Bertino, ed. (New Jersey, Academic Press), pp. 501-508. 
PASQUALINI, R., Arap, W., and MCDONALD, D. M. (2002). Probing the structural and molecular diversity of tumor vasculature. Trends Mol. Med. 8, 563-571.

PASQUALINI, R., ARAP, W., RAJOTTE, D., and RUOSLAHTI, E. (2001). In vivo selection of phage-display libraries. In Phage display. A laboratory manual, C. F. Barbas, D. R. Burton, J. K. Scott, and G. J. Silverman, eds. (Cold Spring Harbor, Cold Spring Harbor Laboratory Press).

PASQUALINI, R., and RUOSLAHTI, E. (1996). Organ targeting in vivo using phage display peptide libraries. Nature 380, 364-366.

PAULSON, D. F. (1987). Management of prostate malignancy. In Genitourinary Cancer Management, J. B. deKernion, and D. F. Paulson, eds. (Philadelphia, Lea and Febiger), pp. 107-160.

POLLACK, E. S., NOMURA, A. M., HEILBRUN, L. K., STEMMERMANN, G. N., and GREEN, S. B. (1984). Prospective study of alcohol consumption and cancer. N. Engl. J. Med. 310, 617-621.

POST, P. N., KIL, P. J., and COEBERGH, J. W. (1999). Trends in survival of prostate cancer in southeastern Netherlands, 1971-1989. Int. J. Cancer $81,551-554$

POST, P. N., KIL, P. J., CROMMELIN, M. A., SCHAPERS, R. F., and COEBERGH, J. W. (1998). Trends in incidence and mortality rates for prostate cancer before and after prostate-specific antigen introduction. A 
registry-based study in southeastern Netherlands, 1971-1995. Eur. J. Cancer 34, 705-709.

PRICE, J. E., BELL, C., and FROST, P. (1990). The use of a genotypic marker to demonstrate clonal dominance during the growth and metastasis of a human breast carcinoma in nude mice. Int. J. Cancer 45, 968-971.

REITER, R. E., and DEKERNION, J. B. (2002). Epidemiology, etiology, and prevention of prostate cancer. In Campbell's Urology, P. C. Walsh, ed. (Philadelphia, Saunders), pp. 3003-3024.

SAMANT, R. S., DUNSCOMBE P. B. and ROBERTS, G. H. (2003). A costoutcome analysis of long-term adjuvant goserelin in addition to radiotherapy for locally advanced prostate cancer. Urol. Oncol. 21, 171177.

SANDBLOM, G., DUFMATS, M., NORDENSKJOLD, K., and VARENHORST, E. (2000). Prostate carcinoma trends in three counties in Sweden 19871996: results from a population-based national cancer register. SouthEast Region Prostate Cancer Group. Cancer 88, 1445-1453.

SAWCZUK, I., TANNENBAUM, M., OLSSON, C. A., and DEVERE WHITE, R. (1985). Primary transitional cell carcinoma of prostatic periurethral ducts. Urology 25, 339-343.

SCHELLHAMMER, P. F., JORDAN, G. H., and EL-MAHDI, A. M. (1986). Pelvic complications after interstitial and external beam irradiation of urologic and gynecologic malignancy. World J. Surg. 10, 259-268. 
SCOTT, J. K., and SMITH, G. P. (1990). Searching for peptide ligands with an epitope library. Science 249, 386-390.

SHIMIZU, H., ROSS, R. K., BERNSTEIN, L., YATANI, R., HENDERSON, B. E., and MACK, T. M. (1991). Cancers of the prostate and breast among Japanese and white immigrants in Los Angeles County. Br. J. Cancer 63, 963-966.

SHIN, B. K., WANG, H., YIM, A. M., LE NAOUR, F., BRICHORY, F., JANG, J. H., ZHAO, R., PURAVS, E., TRA, J., MICHAEL, C. W., MISEK, D. E. and HANASH, S. M. (2003). Global profiling of the cell surface proteome of cancer cells uncovers an abundance of proteins with chaperone function. J. Biol. Chem. 278, 7607-7616.

SLAWIN K., KADMON, D., PARK, S. H., SCARDINO, P. T. ANZANO, M. SPORN, M. B. and THOMPSON, T. C. (1993). Dietary fenretinide, a synthetic retinoid, decreases the tumor incidence and the tumor mass of ras+myc-induced carcinomas in the mouse prostate reconstitution model system. Cancer Res. 53, 4461-4465.

SMITH, G. P. (1985). Filamentous fusion phage: novel expression vectors that display cloned antigens on the virion surface. Science $228,1315-$ 1317.

SMITH, G. P., and SCOTT, J. K. (1993). Libraries of peptides and proteins displayed on filamentous phage. Methods Enzymol. 217, 228-257. 
STANFORD, J. L., WICKLUND, K. G., MCKNIGHT, B., DALING, J. R., and BRAWER, M. K. (1999). Vasectomy and risk of prostate cancer. Cancer Epidemiol. Biomarkers Prev. 8, 881-886.

STEINBERG, G. D., CARTER, B. S., BEATY, T. H., CHILDS, B., and WALSH, P. C. (1990). Family history and the risk of prostate cancer. Prostate 17, 337-347.

TREPEL, M., ARAP, W., and PASQUALINI, R. (2002). In vivo phage display and vascular heterogeneity: implications for targeted medicine. Curr. Opin. Chem. Biol. 6, 399-404.

TRIANTAFILOU, M., FRADELIZI, D., and TRIANTAFILOU, K. (2001). Major histocompatibility class one molecule associates with glucose regulated protein (GRP) 78 on the cell surface. Hum. Immunol. $62,764-770$.

WEBSTER, R. (2001). Filamentous Phage Biology. In Phage Display: A Laboratory Manual, C. F. Barbas, Burton, D.R., Scott, J.K. and Silverman, ed. (Cold Spring Harbor, Cold Spring Harbor Laboratory Press), pp. 1.1-1.37.

WITJES, W. P., SCHULMAN, C. C., and DEBRUYNE, F. M. (1997). Preliminary results of a prospective randomized study comparing radical prostatectomy versus radical prostatectomy associated with neoadjuvant hormonal combination therapy in T2-3 NO MO prostatic carcinoma. The European Study Group on Neoadjuvant Treatment of Prostate Cancer. Urology 49, 65-69. 
YAO, S. L., and LU-YAO, G. (1999). Population-based study of relationships between hospital volume of prostatectomies, patient outcomes, and length of hospital stay. J. Natl. Cancer. Inst. 91, 1950-1956. 